\author{
UNIVERSIDADE DE SÃO PAULO - USP \\ FACULDADE DE ECONOMIA, ADMINISTRAÇÃO E CONTABILIDADE \\ DEPARTAMENTO DE ECONOMIA \\ PROGRAMA DE PÓS-GRADUAÇÃO EM ECONOMIA
}

\title{
The perils of crossing borders: \\ The financial constraints of Brazilian exporters during the 2009 Global Trade Collapse
}

As dificuldades de atravessar fronteiras:

Restrições financeiras dos exportadores brasileiros durante o Colapso do Comércio Global em 2009

Stella Mendes Carneiro

Orientador: Prof. Dr. Márcio Issao Nakane

São Paulo

2018 
Prof. Dr. Vahan Agopyan

Reitor da Universidade de São Paulo

Prof. Dr. Adalberto Américo Fischmann

Diretor da Faculdade de Economia, Administração e Contabilidade

Prof. Dr. Eduardo Amaral Haddad

Chefe do Departamento de Economia

Prof. Dr. Ariaster Baumgratz Chimeli

Coordenador do Programa de Pós-Graduação em Economia 


\title{
The perils of crossing borders: \\ The financial constraints of Brazilian exporters during the 2009 Global Trade Collapse
}

\author{
As dificuldades de atravessar fronteiras: \\ Restrições financeiras dos exportadores brasileiros durante o Colapso do Comércio Global em 2009
}

Dissertação apresentada ao Departamento de Economia da Faculdade de Economia, Administração e Contabilidade da Universidade de São Paulo como requisito parcial para a obtenção do título de Mestre em Ciências.

Orientador: Prof. Dr. Márcio Issao Nakane

Versão Original

São Paulo 
FICHA CATALOGRÁFICA

Elaborada por Rafael Mielli Rodrigues - CRB-8/7286

Seção de Processamento Técnico do SBD/FEA/USP

\section{Carneiro, Stella Mendes}

The perils of crossing borders: the financial constraints of brazilian exporters during the 2009 global trade collapse / Stella Mendes Carneiro. -São Paulo, 2018.

$63 \mathrm{p}$.

Dissertação (Mestrado) - Universidade de São Paulo, 2018.

Orientador: Marcio Issao Nakane.

1. Investimentos 2. Crédito de exportação 3. Comércio internacional I. Universidade de São Paulo. Faculdade de Economia, Administração e Contabilidade. II. Título.

CDD -332.6 


\section{Acknowledgements}

I thank the Coordination for the Improvement of Higher Level Personnel (Capes) for the financial support that made this dissertation and my graduation possible and my supervisor during my Masters, Professor Marcio Nakane, for his teaching, support and advices that were crucial to the development of this dissertation.

I am also very grateful to professors Dante Aldrighi, Mauro Rodrigues and Gabriel Madeira for their participation and suggestions in my Qualification and my Progress Evaluation. 



\section{Abstract}

This paper explores the 2008-2009 Global Trade Collapse to estimate the effects of a credit supply shock on exporters' investments decisions. Using a Brazilian firm-level dataset compiled by the Brazilian Internal Revenue Service (IRS) over the period 2007-2013, I pair up export-intensive firms with their domestically-oriented counterparts to, subsequently, calculate the differences in terms of sensitivity of investment to cash flow between the two groups over the years. After controlling for the effect of international falling demand, my study reveals that exporters are more severely constrained than their peers in the control group only in 2009, when the supply of credit instruments to finance international trade shrank. Given their high need of external financing to support exporting activities and the volatility of the cost of trade finance, usually priced against 3-month Libor, my results are in line with expected. A number of robustness and placebo tests confirm the validity of the findings.

Keywords: credit constraints, international trade collapse, investment decisions. 



\section{Resumo}

Este artigo explora o colapso do comércio global em 2008-2009 no intuito de estimar os efeitos de um choque de oferta de crédito nas decisões de investimento das empresas exportadoras. Utilizando dados em painel de empresas brasileiras no período 2007-2013, compilados pela Receita Federal do Brasil (RFB), é feito pareamento entre empresas exportadoras e as focadas no mercado interno e, em seguida, calculadas as diferenças na sensibilidade do investimento ao fluxo de caixa entre os dois grupos ao longo dos anos. Depois de controlar o efeito da queda da demanda internacional, meu estudo revela que as exportadoras ficaram mais restritas a crédito que suas similares do grupo de controle somente no ano de 2009, quando a oferta de instrumentos de crédito para o setor encolheu. Dada a alta necessidade de financiamento externo para apoiar as atividades de exportação e a volatilidade do custo dos instrumentos de crédito destinados a estas, geralmente precificados em relação à Libor de 3 meses, os resultados obtidos estão em linha com o esperado. Uma série de testes de robustez e placebo são realizados para confirmar a validade das inferências.

Palavras-chave: restrições de crédito, colapso do comércio internacional, decisões de investimento. 



\section{List of Figures}

Figure 1 - World Outlook in 2007-2013 period . . . . . . . . . . . . . . 28

Figure 2 - Main Credit Instruments for Exporters (US\$ bn) . . . . . . . . . . 30

Figure 3 - Brazilian Exports Volume, 1997-2013 . . . . . . . . . . . . . . . 31

Figure 4 - Brazil Export Prices Index, 2007-2013 . . . . . . . . . . . . . . 31

Figure 5 - Average Spread for ACC (p.p.) . . . . . . . . . . . . . . 32

Figure 6 - Total Sample versus Exporters Comparison (\% by Number of Firms) . 39

Figure 7 - Treated and Control Groups - Investments and Cash Flow (Annual Var. \%- Median) . . . . . . . . . . . . . . . . . . 43 



\section{List of Tables}

Table 1 - Exporting Criteria . . . . . . . . . . . . . 35

Table 2 - Sample Size by Category . . . . . . . . . . . . . . 38

Table 3 - Balance Summary . . . . . . . . . . . . . . . . 41

Table 4 - Treated and Control Groups - Variable Means . . . . . . . . . . . . 44

Table 5 - Fixed Effects Estimation . . . . . . . . . . . . 46

Table 6 - Robustness Tests Definition . . . . . . . . . . . . . 47

Table 7 - Robustness Test 1 - Treatment with exports-to-sales ratio over $75 \%$. . 48

Table 8 - Robustness Test 1 - Treatment with exports-to-sales ratio over $25 \%$. . 49

Table 9 - Robustness Test 2 - 1-to-2 matching . . . . . . . . . . . . 50

Table 10 - Robustness Test 2 - 1-to-8 matching . . . . . . . . . . . . . 51

Table 11 - Robustness Test 3 - Adding Cash Flow covariate . . . . . . . . . . . . 52

Table 12 - Placebo Test - Fake treatment group . . . . . . . . . . . . . 54

Table 13 - Dataset composition by number of observations per firm . . . . . . . 63 



\section{Contents}

Introduction $\ldots \ldots \ldots \ldots \ldots \ldots \ldots \ldots$

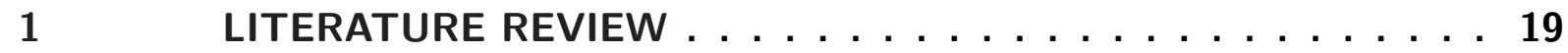

1.1 Investment-cash flow sensitivities model . . . . . . . . . 19

$1.1 .1 \quad$ Sorting criteria . . . . . . . . . . . . . . . . 20

1.1.2 A proxy for internal sources of finance . . . . . . . . . . . 21

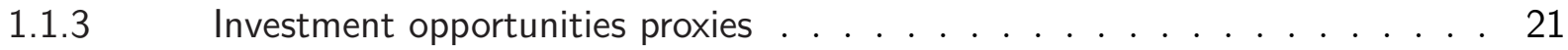

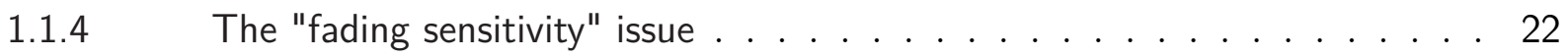

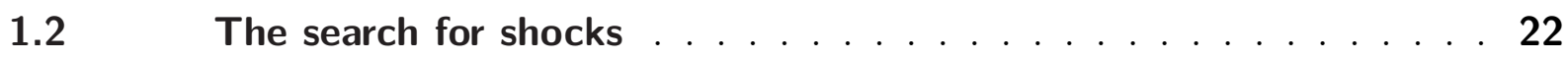

$1.2 .1 \quad$ Early evidence . . . . . . . . . . . . . . . . . . 23

1.2.2 Recent disruptions in Credit Markets . . . . . . . . . . . . . . . . 24

2 THE 2009 TRADE COLLAPSE AND ITS AFTERMATHS IN BRAZIL 27

2.1 Credit Instruments for International Trade in Brazil . . . . . . . . 29

2.2 Macroeconomic Environment . . . . . . . . . . . . . . 29

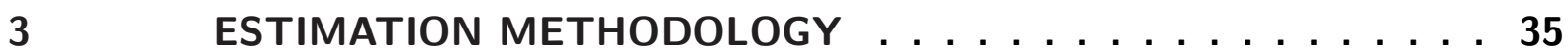

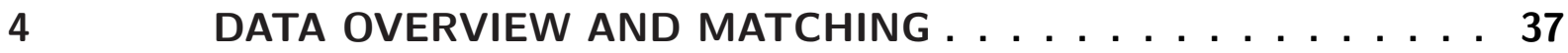

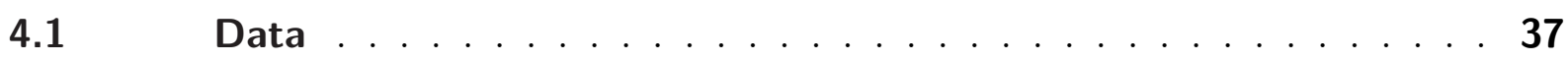

$4.2 \quad$ Matching Analysis $\ldots \ldots \ldots \ldots \ldots$

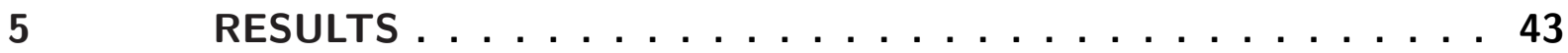

5.1 The Investment Response . . . . . . . . . . . . . 43

5.2 Baseline Results . . . . . . . . . . . . . . . . . . . 45

5.3 Robustness Tests . . . . . . . . . . . . . . . . . . . . . 47

$5.4 \quad$ Placebo Tests . . . . . . . . . . . . . . . . 53

Concluding remarks $\ldots \ldots \ldots \ldots \ldots \ldots$

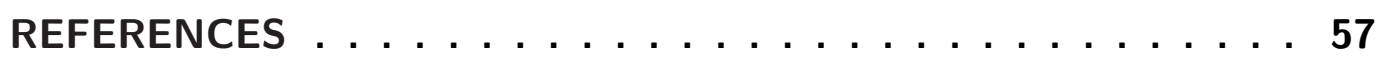

$\begin{array}{ll}\text { APPENDIX } & 61\end{array}$

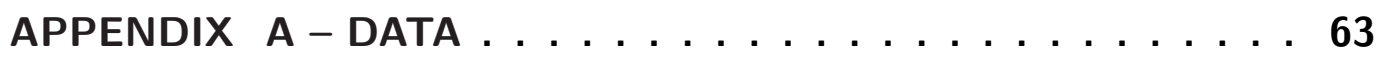

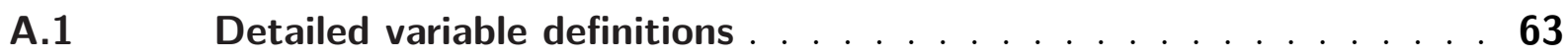

A.2 Sample Profile . . . . . . . . . . . . . . . 63 



\section{Introduction}

On September 2008, the Lehman Brothers bankruptcy filling burst the United States (U.S.) subprime mortgage crisis. What was initially a financial crisis to developed economies soon spilled worldwide via two main channels: the credit crunch, as banks sought-out more liquid assets and reduced lending; and the unprecedented reduction on demand for exports, known as the "Global Trade Collapse". Both channels are well-known to be strongly correlated considering that, when world trade felt 17 percent between the final quarter of 2008 and the first quarter of 2009, banks were not able to meet customer demand to finance international trade operations, creating an estimated US $\$ 25$ billion dollar deficit in the supply of trade finance (LAWRENCE; HANOUZ; MOAVENZADEH, 2009).

As Ahn, Amiti and Weinstein (2011) describes, ever since this episode the major challenge for the macroeconomic literature has been to conceive how standard econometric models could incorporate finance-based explanations to this negative scenario for the exporting sector in 2009. Hereof, this article provides some evidence of the impact of funding shortage on Brazilian exporters' investments.

In Brazil, the macro backdrop in the period was less overwhelming compared to developed economies. Given the soundness of the local financial system and its low exposure to the mortgage-backed securities that triggered the financial crisis, local credit markets were not immediately harmed. Consequently, the slowdown in economic activity of its major trading partners was reckoned as the main culprit for the downfall in exporting firms investments (CHEUNG; GUICHARD, 2009).

Yet, there is mounting evidence suggesting that credit tightening may have been an issue to Brazilian exporting sector as well. Unlike other credit lines, those designated for exporters rely on the availability of external financing in foreign currency, which, in turn, depend on the liquidity situation of the international markets. From July 2008 to June 2009, the supply of the two main credit instruments for exporters (the Advances on Foreign Exchange Contract and Advanced Payments method) declined over 25\%, while their spread rates reached historical peaks and remained high even after the fast recovery of export prices. Meanwhile, the supply of traditional credit designated to the overall corporate sector increased over $20 \%$.

The episode, therefore, arguably provides a natural experiment to test firms funding constraints. As I am mostly interested in studying the role of firms' funding conditions in mitigating or worsening the impact of the crisis on investment, my empirical approach starts with the pairing up of export-intensive firms with their domestically-oriented counterparts 
on the basis of some characteristics (size by number of employees and total assets value within sector).

In this intent, I employ a dataset compiled by the Brazilian Internal Revenue Service (IRS) over the period 2007-2013 including 32,737 firms in 18 different sectors, mainly medium-size private firms. Only 130 of them were export-intensive in 2009, which compose the "treatment" category in this study. Nevertheless, the large number of domesticallyoriented firms allows me to construct a control group that serves as an good counter-factual, which is built by pairing up firms in the two groups on the basis of sector classification and size characteristics.

After, to address endogeneity concerns, I combine matching and difference-indifferences (DID) approach by estimating a weighted fixed effects model with interactions between the treatment group and time dummies. Additionally, I employ traditional timevarying control for investment opportunities. The results from these regressions can be interpreted as causal effects if the treatment status (being export-intensive in 2009) is strictly exogenous to the shock.

The findings of this study seem to suggest that financial constraints play an important role in shaping investment decisions of Brazilian exporters during global trade turmoils: (i) the relation between cash flow and investments is positive and statistically significant to all firms, although it is overall rather low; (ii) in years of greater macro stability, the difference in exporters funding shortage compared to its market peers is not significant, while it has became large and significant in 2009, during the trade collapse. A number of placebo tests suggest that my inferences are not confounded with other factors. To the best of my knowledge, this is the first paper to address the "Global trade collapse" episode as a possible shock to credit markets in Brazil.

This work unfolds as follows. Section 1 presents the background literature in corporate finance for the relationship between investment and cash flow. Section 2 presents an overview of Brazilian credit markets for exporters and the aftermaths of the Global Trade Collapse for the sector. Section 3 presents the methodology used for estimating the regressions. Section 4 describes the data and presents some descriptive statistics. Section 5 presents the empirical results. Finally, the last chapter discusses the results and future investigations. 


\section{Literature Review}

The analyses of theorists on the importance of firm's financial structure for investment has its origin in the neoclassical theory of investment, developed by Modigliani and Miller (1958). Their work highlighted the irrelevance of capital structure and financial policy for real investment under perfect market conditions. ${ }^{1}$ In our bewildered world, however, a variety of distortionary forces lying in the actual business cycles, such as informational asymmetries and agency problems, rule out the applicability of the financial independence presumption.

A vast literature explores these forces on the economy, more specifically, seeking to explain the effects of market frictions to corporate sector's investments. As presented in the next sections, different papers have addressed financial constraints' existence and its impact in different ways. The first strand of the literature shares a common ground in their belief of the link between internal funds and investment spending. But a second class of papers gainsays this correlation, arguing that it suffers from omitted variables bias. They observe, instead, investment and other corporate variables responses to exogenous shocks on the supply of funds.

My study unites these two research agendas. It is the first one, to my knowledge, that combines a large-sample estimation investment-cash flow model with the use of the credit market disruption during the 2009 Global Trade Collapse as an exogenous shock for exporters.

\subsection{Investment-cash flow sensitivities model}

The work of Fazzari et al. (1988) (FHP) was the first to empirically test the role of information problems in firms' supply of credit using disaggregated data. Their seminal paper analyses the influence of financing frictions on corporate investment by comparing the empirical sensitivity of investment to cash flow (their proxy for net worth) in three different groups of firms divided according to their dividend payment yields (high, medium or low). The results showed that the low dividend yield group experienced substantially greater sensitivity of investment to cash flow, which was interpreted as evidence of financial constraints: firms paying low yields do so because they urge to retain internal funds. After all, self-funding is costless, but raising debt or equity requires a premium.

Kaplan and Zingales (1997) later questioned the robustness of the FHP model by

\footnotetext{
${ }^{1}$ The Modigliani-Miller Theorem (Modigliani and Miller, 1958) states that under efficient markets with absence of transaction costs and information symmetry, investments are not affected by the capital structure of the firm.
} 
revisiting the sample used for estimation and analyzing firms' annual reports. Based on their interpretation, cash flow sensitivity was greater not among these arguably constrained firms, but among those that were least constrained. In the next subsections, I discuss the main issues of the cash flow sensitivity model and the subsequent literature that attempt to overcome them.

\subsubsection{Sorting criteria}

Investment-cash flow sensitivities models regularly assume that, by a firm's actions (such as not paying dividends) or characteristics (being young, small, low-leveraged or not having a credit rating), it is possible to infer about cross-sectional differences on internal funds' effects to investments. This is the reason why the empirical strategy to define groups of firms as "constrained" or "unconstrained" at a certain point of time often starts with an a priori classification of firms according to measures assumed to be correlated with information costs.

The use of this method is controversial. Beck et al. (2006) have demonstrated that size, age and ownership could be reliable predictors for financing obstacles based on a survey containing a large number of questions on the nature and severity of obstacles for firms around the world. For Farre-Mensa and Ljungqvist (2016), on the other hand, some popular measures employed, such as dividend payment policy and credit rating status, as well as compound indices, are inaccurate. ${ }^{2}$ In their sample of listed firms, the ones defined as "constrained" by these criteria do not behave as such: they are able to increase their leverage significantly when their demand for debt increases exogenously; they are not sensitive to a exogenous variation in the supply of bank loans; and do not have the tendency of paying out shareholders' proceeds from equity issues. ${ }^{3}$

Forthrightly, even though this strategy is analytically convenient, it is feasible that, in reality, firms switch between "unconstrained" and "constrained" as their financial situation changes. Particularly, changes in net worth value, investment opportunities and accumulated liquidity can have a striking impact on their ability to raise external funding (HUBBARD, 1997). The severity of agency costs, for instance, might fluctuate as firms' net worth changes, altering the length of the supply-of-funds curve's horizontal segment.

\footnotetext{
${ }^{2}$ Indices that measure the degree of financial constraints - such as Kaplan-Zingales, Whited-Wu, and Hadlock-Pierce - are beyond the scope of this work. See Farre-Mensa and Ljungqvist (2016) for references on the subject.

${ }^{3}$ The firm-level data are taken from the World Business Environment Survey (WBES), which is a major firm-level survey conducted in 1999 and 2000 in 80 developing and developed countries around the world and led by the World Bank.
} 


\subsubsection{A proxy for internal sources of finance}

A firm's internal net worth cannot be directly calculated using balance sheet data. This brought the need to find proxies related to its "funding capacity", i.e. disposable cash or collateral assets that can back external financing. The most commonly used proxy in the literature is cash flow. Even though it is not a very precise one, since it can also reflect strategic accounting decisions (timing and financial) not correlated with net worth, in most cases it is the only one available (HUBBARD, 1997).

Some alternative proxies available are: the amount of short-term securities at the beginning of the period; total debt as a fraction of total assets and short-term debt as fraction of short-term assets. ${ }^{4}$ However, all of them (including cash flow), have the same limitation: they measure the book rather than the market value of a firm's internal sources of finance. Hence, there is no guarantee that any proxy is able to correctly measure the effects of economic shocks on firms' internal sources of finance.

The recent literature has taken on the task of finding exogenous instruments for internal net worth using shocks to cash and collateral that are not correlated with the returns to investment. The basic idea is to find natural experiments in which one can identify specific changes in the cost of finance (LAMONT; POLK; SAAÁ-REQUEJO, 2001). This approach will be discussed in more detail in Section 1.2.

\subsubsection{Investment opportunities proxies}

Fazzari et al. (1988) had acknowledged that shocks to cash flow can have a dual effect: an instantaneous increase in funding and a potential improvement in future profitability. The major concern was that $Q$, the control variable in their model, would only capture outsiders' evaluation of future opportunities, while it is possible that cash flow affects investment simply because it is correlated with the insiders' evaluation of opportunities, a critical measurement error for the model (GUARIGLIA, 2008).

Moreover, an appropriate measure of investment opportunities would capture the firm manager's expectation on the present value of future profits from additional capital investment. The value of marginal $\mathrm{Q}$ is assertively the variable that most suits this definition. Yet, its use in empirical models was criticized because what can be constructed using real data (average Q) is equivalent to what in theory reflects investments opportunities (marginal Q) only under strong assumptions (GILCHRIST; HIMMELBERG, 1995; ERICKSON; WHITED, 2000; HAYASHI, 1982). ${ }^{5}$ In the real world, imperfect competition and interrelationship of firms' investment and financing decisions would

\footnotetext{
${ }^{4}$ See Vermeulen (2002) for a complete review of these alternative proxies.

${ }^{5}$ Hayashi (1982) demonstrated that marginal $\mathrm{Q}$ is equal or proportional to average $\mathrm{Q}$ under the assumptions of: (i) production and adjustment cost technologies are linear homogeneous; (ii) investment and capital are homogeneous; and (iii) perfect competition.
} 
violate these assumptions.

For these reasons, one part of the subsequential related papers explored the need to find the right control variables, capable of overcoming possible measurement error issues in proxies for investment opportunities. Almeida and Campello (2007) examined the role of asset tangibility in the firm's ability to obtain external resources and propose a new identification strategy: if firms were financially constrained, investment-cash flow sensitivities should be increasing in the tangibility of firms' assets. Carpenter and Guariglia (2008) included the firm's contractual obligations for new projects as an additional proxy, which would capture information about opportunities available only to insiders and thus not measured in $\mathrm{Q}$.

\subsubsection{The "fading sensitivity" issue}

Recent literature employing the FHP model for long time spans' samples has evidenced an uncanny trend: the decline and disappearance of investment-cash flow sensitivity over time. Some authors with a rather optimistic perception point out two possible explanations for this "development": improvement in informational efficiency of capital markets; and the increase in supply of funds to capital markets, resulting in easier access to external capital, especially for small high-growth firms (ALLAYANNIS; MOZUMDAR, 2004; AĞGA; MOZUMDAR, 2008).

All these hypotheses might sound unrealistic if one believes that financial constraints have not disappeared. More plausibly, the changing composition of investment, specially the decreasing importance of physical investment is responsible for this reduction in investment-cash flow sensitivity (BROWN; PETERSEN, 2009). Also, there is a consensus among authors that this decline can be partially explained by the measurement errors previously presented. ${ }^{6}$

Consistent with this view, Chen and Chen (2012) found that the information content in cash flow regarding investment opportunities has declined over time, as evidenced by the declining patterns in the correlation between cash flow and Tobin's Q. Additionally, cash flow has become less persistent. As efficiency issues of the model cannot solely justify these patterns, economic or financial reasons that could support them remain unraveled.

\subsection{The search for shocks}

Perhaps the cleanest evidence of the financial factors' effect on corporate behavior comes from a series of "natural experiments", capable of isolating shocks to firms' financial

\footnotetext{
${ }^{6}$ Allayannis and Mozumdar (2004), Ağca and Mozumdar (2008), Brown and Petersen (2009), Chen and Chen (2012) all mention how Tobin's Q and cash flow measurement errors help explain the decline in investment-cash flow sensitivity.
} 
positions from their investment opportunities. A growing trend in the literature is to delve into these events that could provide resourceful identification strategies to measure the impact of credit constraints on investments. Inside the business cycle conjecture, they can arise either from the demand side, with a disruption on internal net worth; or from the supply side, on debt and equity finance markets.

\subsubsection{Early evidence}

The link between credit shrinkage, capital structure and investment decisions was first established by the empirical work of Bernanke, Lown and Friedman (1991). Most of incipient studies, though, did not manage to adequately isolate supply shocks from demand factors, and vice versa. They were subjected to the same standard criticism faced by cash flow sensitivity models on their use of firm-level variables: the inability of properly control investment opportunities in the event of shocks. The next paragraphs reveal some of the early strategies used in the cumbersome task of identifying shocks, both to internal and external capital, that worked in the transmission of business cycles but were not, ostensibly, correlated with the expected returns of projects.

As discussed in Section 1.1, "internal net worth" implies either on additional funds available for internal finance or on additional collateral to back external finance. Hence, shocks on the borrower-side are either through one of these two variables. Lamont's (1997) strategy was to investigate how cash shortfalls at a firm's specific division alters the shadow cost of investments in other unrelated divisions. More specifically, how the 1986 oil price decline affected oil companies in their "non-oil" segment. These results were further generalized to other industries, compiling evidence of an active internal capital market inside corporations (HOUSTON; JAMES; MARCUS, 1997; SHIN; STULZ, 1998). However, there are methodological caveats about selection biases in these crosssubsidization studies: their experimental design posits that divisions of multi-industry firms are randomly allocated, but it is fairly possible that firms from different divisions share common influence factors, such as being exposed to the same regional economic conditions, which would invalidate this hypothesis of randomness (CHEVALIER, 2004).

Other exogenous shocks to cash might come from institutional changes in tax policies, as in Farre-Mensa and Ljungqvist (2016), or mandatory contributions to pension funds (Rauh (2006), Bakke and Whited (2012)). For collateral, land market disruptions and financial distress on market peers have shown influence on firms' funding status. Gan (2007) explored how Japan's land market collapse during the 1990s worsened firms debt capacities, and Carvalho (2015) studied how bankrupted firms can signalize negative information about their industry to investors, wide-spreading valuation losses to peers, and thereby, amplifying downturns.

Yet, the studies mentioned so far only restate the importance of internal net worth. 
When lender-side disruptions are analyzed, the role of capital structure on investments is shown from an alternative perspective, essentially because they help on the identification of the link between the supply of credit and corporate behavior instead. The challenge, in this case, is to untie supply-side forces from demand ones.

For a few influential papers it was feasible to minimize the concerns about endogenous demand effects using near-concurrent events in their estimations and paired control groups. Leary (2009) used two events of opposite effects on the supply of financing: the emergence of a market for certificates of deposits in 1961 and the credit crunch, in 1966. Small firms, the bank dependent ones by assumption, are paired with others with access to public markets (the control group). Lemmon and Roberts (2010) used the collapse of leading firms in the junk bond market and the change in the credit rating guidelines in 1990 to observe changes in investments of below-investment-grade firms, the treatment group, compared to unrated ones. Both papers find that the substitution of bank debt to alternatives sources of capital are limited for treated firms, leaving them credit constrained during recession episodes.

As international trade shocks are more rare, studies that explore exporters' funding constraints are less recurrent in this literature. Amiti and Weinstein (2011) uses the Japanese banking crisis in the 90s to document how the shrinking of trade finance supply is associated to slower growth of exporters' sales. Iacovone and Zavacka (2009) employs cross-country data from several historical banking crisis to show that the higher is the sector's external finance dependence, the lower is its exports growth during credit crunches.

\subsubsection{Recent disruptions in Credit Markets}

Given the financial origin of the 2008 crisis, several papers investigate its aftermaths in terms of funding constraints and liquidity shortages. Duchin, Ozbas and Sensoy (2010) showed that corporate investment declined significantly during the onset of the crisis, specially among firms with low cash reserves or that operate in industries that were dependent on external finance. Almeida et al. (2012) exploited the maturity structure of corporate long-term debt as an instrument for measuring financing constraints. In their view, as firms find it difficult to substitute across alternative funding sources during downturns, soon-to-mature debt might effectively reduce corporate investment. Accordingly, they find a greater decrease in investment for firms with maturity "spikes" during the crisis.

Following the failure of Lehman Brothers, concerns about the soundness of the U.S. credit and financial markets led to a tightening of the global credit markets around the world. Although there is no question that demand played its part on the 2009 world trade fall, there is increasing evidence that this liquidity contraction that rocked the financial world also contributed to the global trade shortfall. As mentioned in Bricongne et al. 
(2012, p. 134-135), "even in normal times, finance is particularly important for trade for at least three reasons: exporting entails important fixed costs such as the costs of learning about export market profitability, foreign distribution networks, regulatory compliance, etc. Second, exporting is a more risky activity than domestic transactions only. Third, exporting involves longer lags between production and delivery, with median shipment times of 2-3 months. Hence, exporters often need well functioning credit lines to maintain healthy cash flows."

Accordingly, this recent international trade crisis has renewed the academic interest on the role of credit instruments to back exporting activity. There is a recent complementary body of evidence on firm-level data showing that exporters whose financial institutions became unhealthy cut back on exports more than other firms (AHN; AMITI; WEINSTEIN, 2011). These effects were especially pronounced in sectors that require extensive external financing, few pledged assets, or with limited access to trade finance (CHOR; MANOVA, 2012). In addition, export-intensive firms inability to use trade finance as an alternative source of finance contributed to the larger decline in sales experienced by them (COULIBALY; SAPRIZA; ZLATE, 2013).

Nevertheless, this is still a debatable matter. Levchenko, Lewis and Tesar (2011), Behrens, Corcos and Mion (2013) and Bricongne et al. (2012) find no evidence of banking credit's relevance on the trade collapse. For them, it was essentially a demand-driven crisis. My work intends to be a part of this prolific literature that investigates the effects of the 2009 trade collapse. Apart from Paravisini et al. (2014), which uses a sample of Peruvian firms, no other paper has showed to what extent the liquidity squeeze in the period impacted emerging-markets exporters. 



\section{The 2009 Trade Collapse and its after- maths in Brazil}

International trade expanded extensively during much of the past decade, boosted by globalization trends and supported by a favorable international environment, a period known as "the Great Moderation". But as soon as the financial market bubble burst in late 2008, global trade declined significantly more than output. From 2008 to 2009, real world GDP fell by about 0.6 percent, while real world trade by about 10.7, as described in Figure 1. From the earliest days of the crisis, analysts suspected of shrinking credit supply as a contributing factor to the trade collapse.

However, the negative impacts of the crisis did not reach all countries at the same time and with equal force. Hence it is possible, depending on the country and its credit market's characteristics, that the great trade collapse was mostly associated to a demand shock. For developed economies, the financial crisis was since the beginning characterized by a severe credit crunch, as banks were unwilling to lend even to good borrowers. But in emerging countries, the 2008-2009 Trade Collapse unfolded, at first, as a demand-driven shock, which harmed more the productive sector relying on international markets. Later, as an additional effect, greater risk aversion and liquidity concerns spread through their financial system, such as in the Brazilian case. 
Figure 1 - World Outlook in 2007-2013 period

(a) Trade Volumes

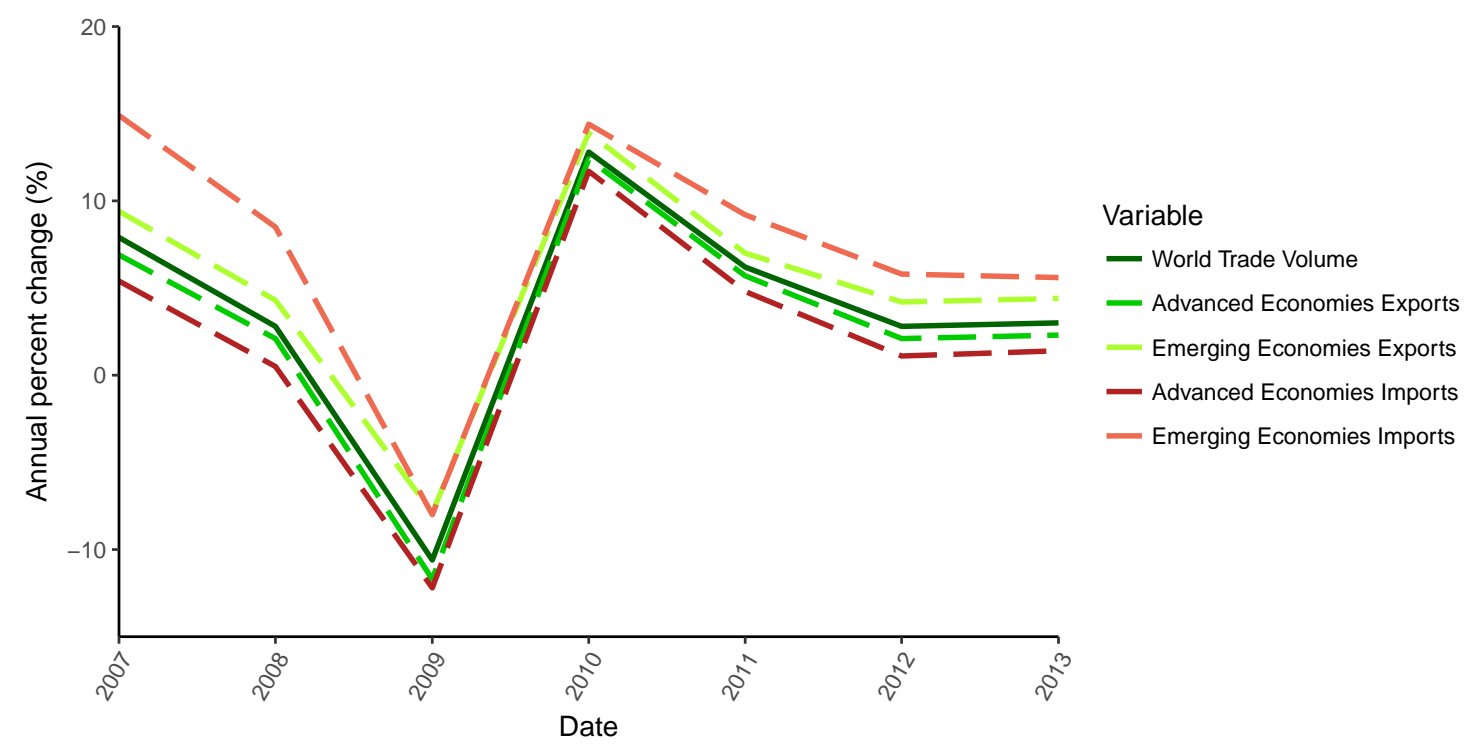

(b) Output

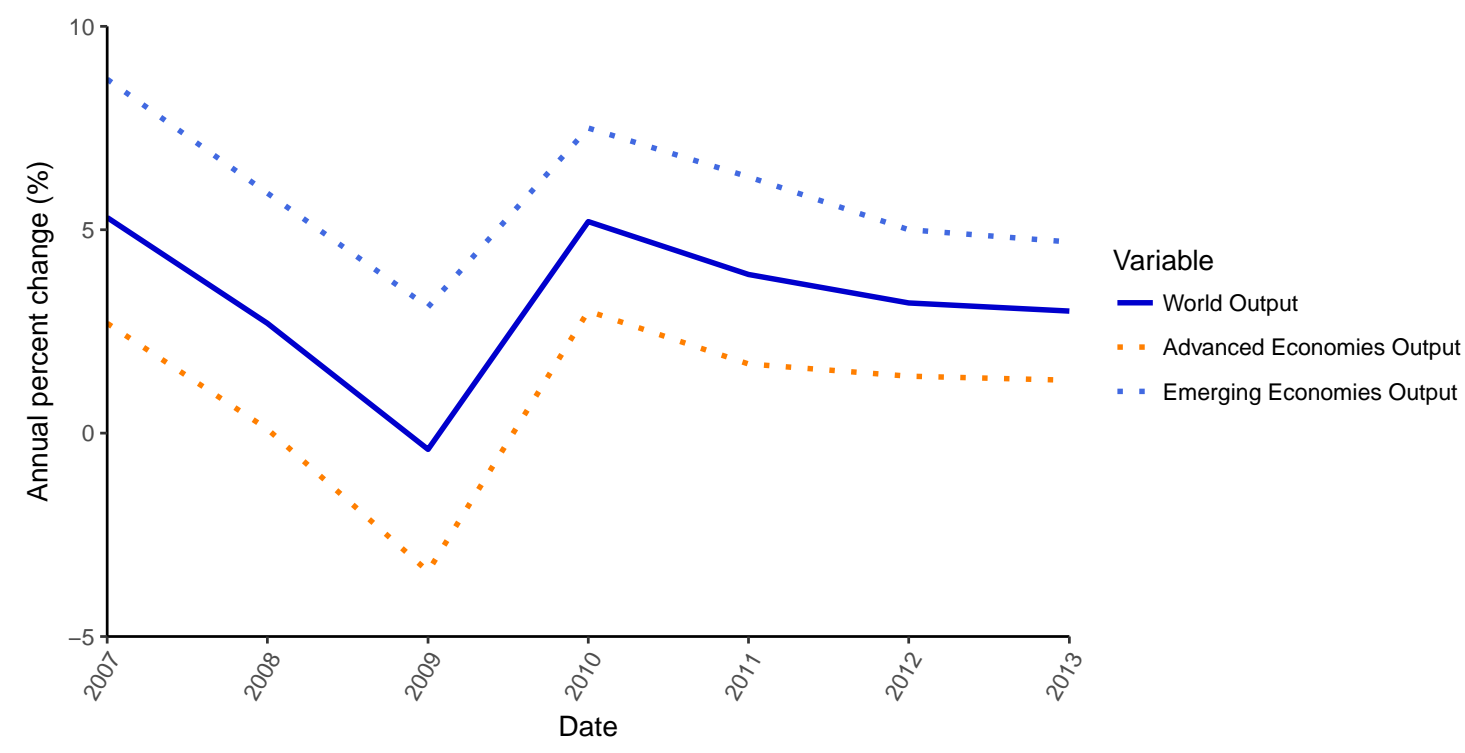

Source: Own elaboration based on (IMF, 2010).

This section presents a brief outline of the main credit instruments available for Brazilian exporters in the 2008-09 period. Further, I explore the aftermaths of the financial crisis and global trade collapse in Brazil, providing some stylized facts of the period in the intent of showing the "Lehman-link", which, through the instability in international markets, disrupted local credit conditions for exporters. As 80-90 percent of world trade relies on some form of trade finance, understanding the interplay between macroeconomic environment and external funding supply for the sector is of sheer importance for policy makers aiming to provide the correct supply-side stimulus to future exporting activity (CHAUFFOUR; FAROLE, 2011). 


\subsection{Credit Instruments for International Trade in Brazil}

Essentially, there are three main credit instruments that work as payment methods to international trade for Brazilian exporters: Advances on Foreign Exchange Contracts (ACC), Advanced Payment (AP) and BNDES-Exim, shown in figure 2. Together they correspond to over $90 \%$ of the credit volume designated to exporters in the country (GALETTI; HIRATUKA, 2013). They are the most vital resources a exporter has to succeed in foreign markets, offering customers attractive sales terms and providing firms with enough resources to finance their working capital and investments.

The ACC was the most used credit type between 2008-2013. It consists in a prepayment of resources in national currency (BRL) to the exporter, made by a financial institution, before the good is shipped. It provides the immediate acquisition of the local currency for the exporter to finance the production of goods, but maintains its debt with the financial institution in dollars, once the revenue from its sales also continues to be in dollars, eliminating any exchange rate risk. The ACC funds are raised abroad by resident banks operating in Brazil. Their loan interest rates usually follow international levels, which are often low for Brazilian standards. The flexibility of guarantees and terms also contributes to make this instrument the most democratic one, helping companies of all sizes and sectors to export.

The second most important instrument is the AP, that relies entirely on credit concessions of foreign bank agencies. Brazilian banking institutions act as mere service providers in this funding process, not as an intermediary as in ACC. For the exporter, the AP also differs from ACC is terms of maturity: while ACC maturity is one year at maximum, AP average maturity is two to three years (ROSSI; PRATES, 2010).

The last and least relevant of the credit instruments comes from public sources: the BNDES-Exim. This credit line has a counter-cyclical demand highly influenced by the other two instruments. Although its cost in relation to ACC and AP varies by sector and firm profile, the BNDES-Exim has the disadvantage of taking longer periods for line approval than the others. Also, high requirements in terms of credit guarantees and collateral often hamper its acquisition by small and medium-sized companies.

\subsection{Macroeconomic Environment}

Figure 3 depicts the evolution of total exports in the 1997-2013 period and Figure 4 its prices index. From 1999 to 2009, Brazilian exports were on the rise, in both prices and volume, a trend intensified by the 2000s commodities boom. In 2009, when world trade experienced a sudden synchronized collapse, exports volume and aggregate prices felt more than $20 \%$ within an year. 
Figure 2 - Main Credit Instruments for Exporters (US\$ bn)

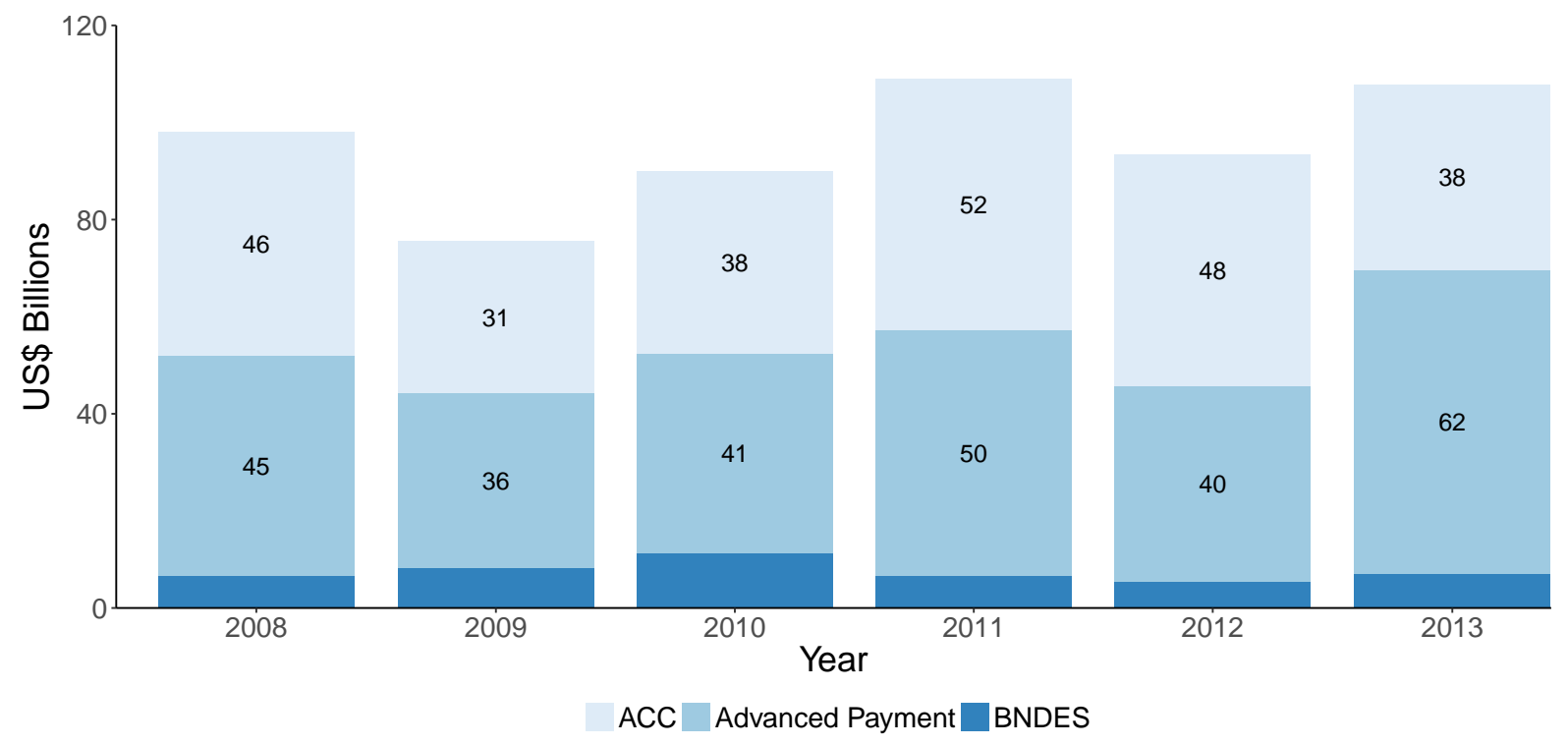

Source: Own elaboration based on BCB and BNDES data. Note: After 2009, Brazilian export sales bounced back reaching record highs, but the volume of credit hired was lower than pre-Lehman levels.

This trade downturn was only a temporary setback comprising the year of 2009. In 2010, trade figures rebound and exceeded 2008 levels volume-wise. The exports record, however, contrasts with the sluggish recovery in credit market conditions to exporters. The cost of credit letters and other similar instruments in the years following the crisis remained higher than in pre-Lehman period. The ACC Spreads, for instance, depicted in Figure 5, declined slowly over the next two years of the crisis, returning to pre-Lehman levels only by the end of 2011.

Although the Brazilian corporate sector was not immediately affected by any banking system instability at the beginning of the crisis, it scattered via indirect channels. Surely, the most pronounced one was the fall of international demand. But the Lehman Brothers collapse served as a wake-up call for Central Bank and federal government to intervene. The Brazilian Central Bank (BCB) was the first compelled to do it, since the episode triggered an increase in the cost of credit instruments for exporters.

In September 2008, the average interests rates for the Advances on Foreign Exchange Contracts (ACC) reached more than $10 \%$ (it was not much higher than $6 \%$ throughout 2007). The BCB promptly reacted with US dollar auctions to banks with the purpose of providing funding for trade finance. Financial institutions who won the bids were entitled to receive dollars for its Advances on Foreign Exchange Contracts (ACC) and Advances on Foreign Exchange Advances (ACE) from the BCB in advance, which represented relief to constrained exporters.

Credit markets were responsive, but the policy's effect was brief. After a few months, the counter-cyclical policy was offset by banks' greater risk aversion. The endorsement of 
Figure 3 - Brazilian Exports Volume, 1997-2013

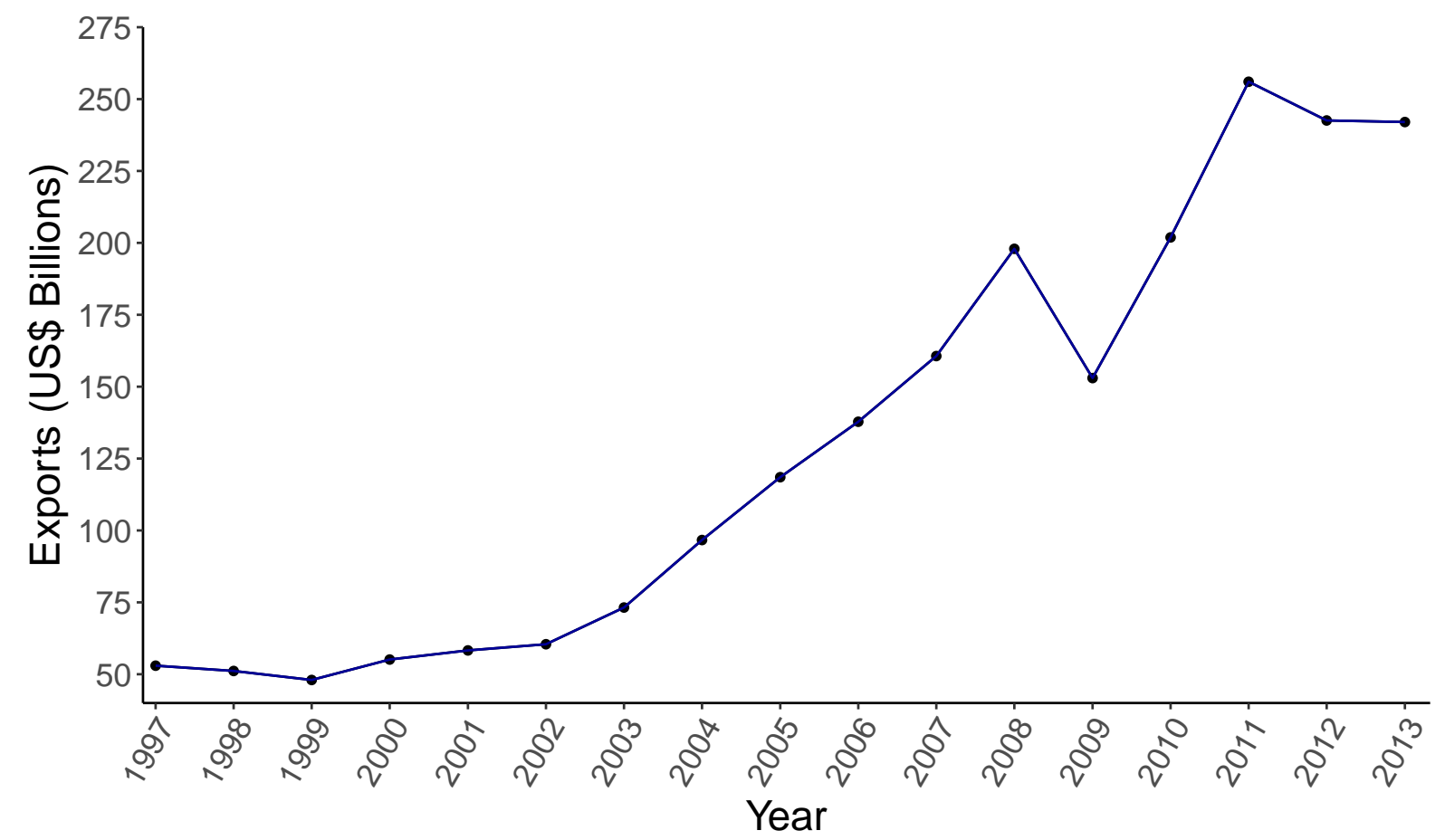

Source: Own elaboration based on Ministry of Industry, Foreign Trade and Services official data: <http:// www.mdic.gov.br/index.php/comercio-exterior/estatisticas-de-comercio-exterior/series-historicas $>$. Note: Total exports values in US\$ FOB.

Figure 4 - Brazil Export Prices Index, 2007-2013

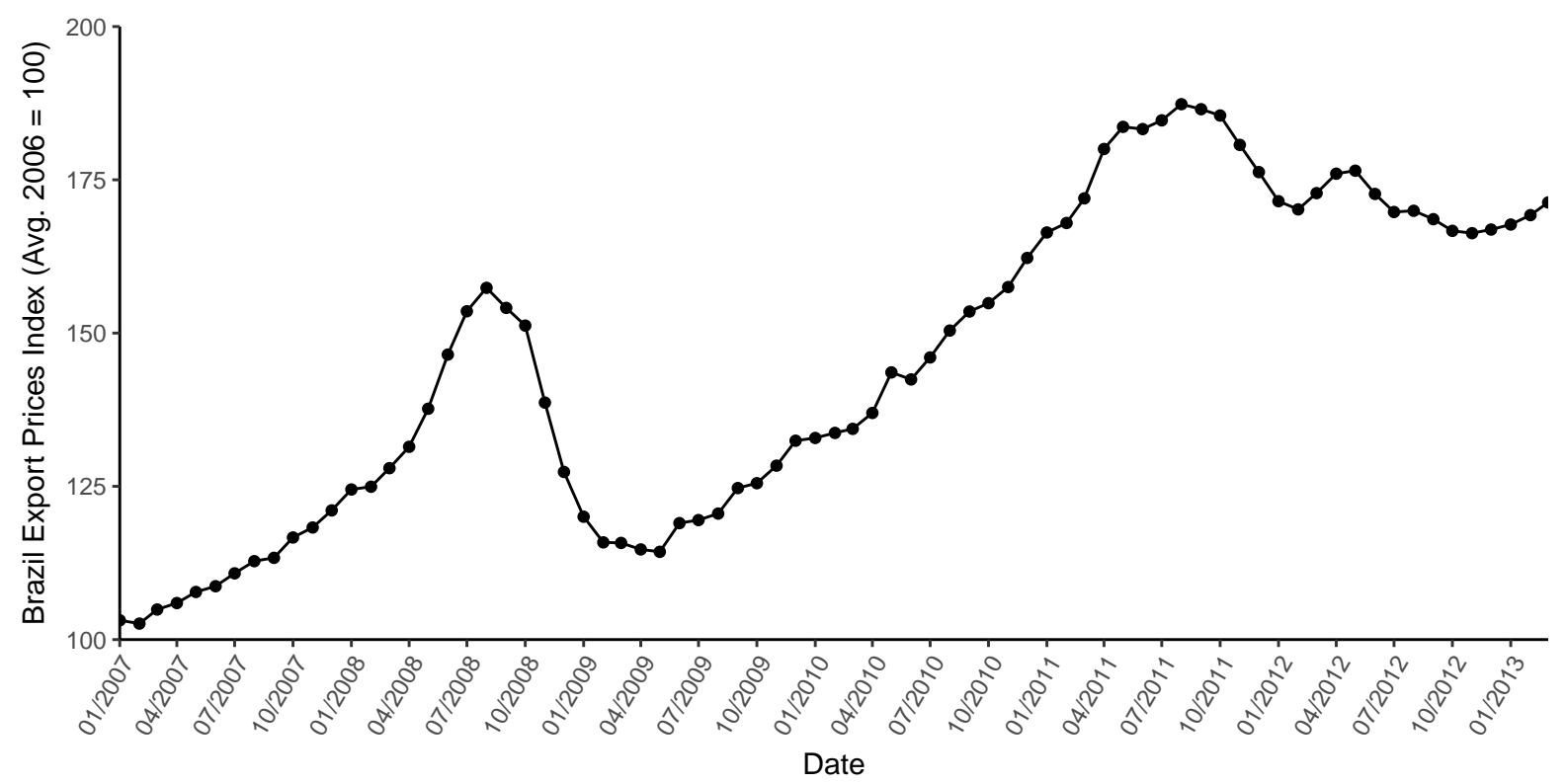

Source: Funcex

more stringent credit criteria and capital allocation restrictions diminished credit lines for exporters while ACC spreads kept rising, as shown in Figure 5. For companies, a higher cost of funding posed the challenge of substituting external sources of funding for internal 
ones.

Figure 5 - Average Spread for ACC (p.p.)

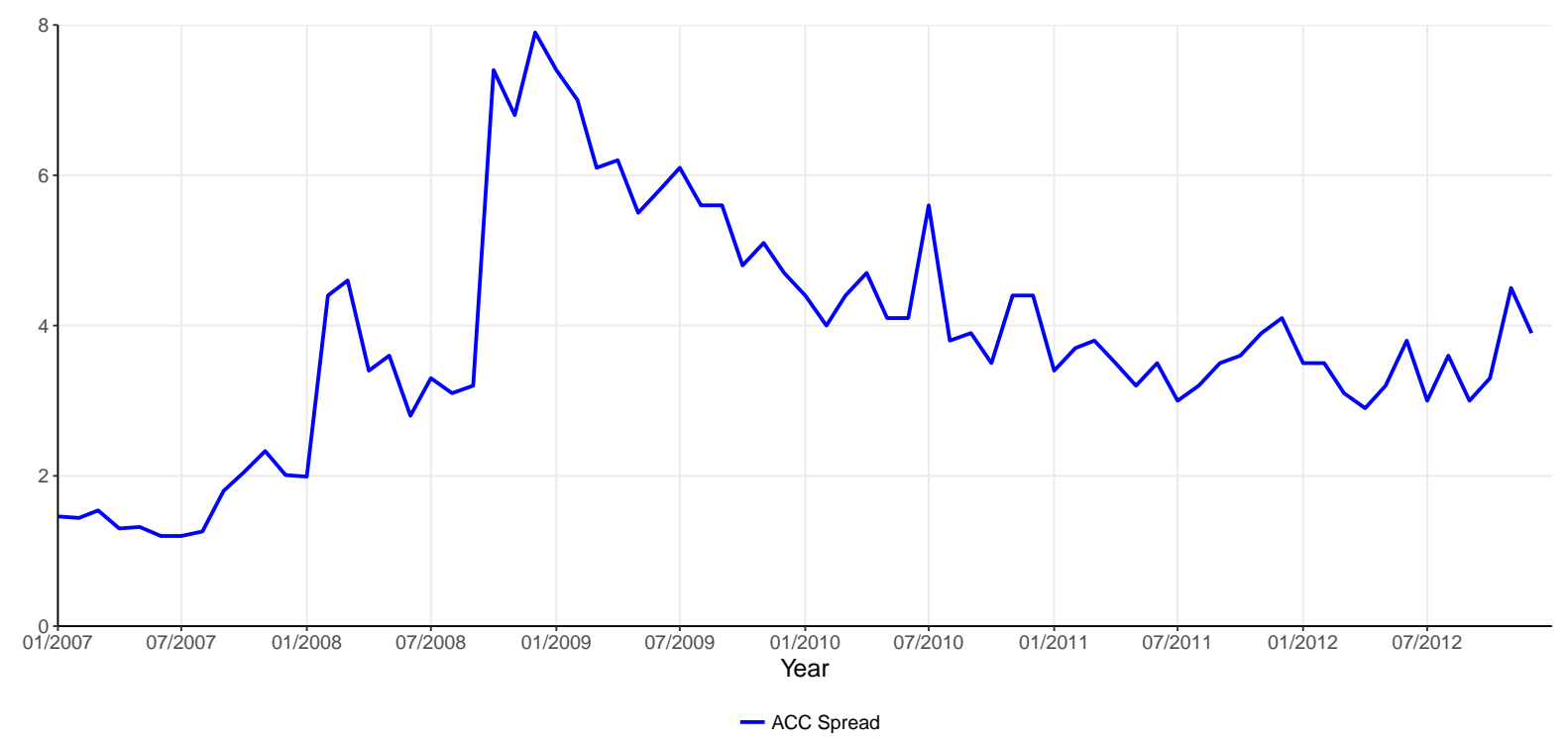

Source: BCB. Note: In addition to the Libor, banks charge a spread for ACC contracts. The spreads rally after the Lehman bankruptcy announcement in September 2008, and later declined with the BCB's dollar auctions but never returned to pre-Lehman levels.

Despite the failure, the intervention set the tone for the subsequent ones. In addition to stimulating the expansion of private bank lines, public banks were in charge of counteracting the scarcity of funds. During the year of 2009, the federal government increased the amount of Treasury funds transferred to BNDES to finance exporting activity. The expansion occurred for both the production (Pre-Shipment Line) and for commercialization (Post-Shipment Line), reaching US\$ 8.3 billion disbursed by the bank. The amount, though, corresponded to less than $15 \%$ of total credit to exporters. Exporters' major liquidity providers, Advanced Payments and ACC, both felt in 2009 and did not recover in 2010, even after export sales bounced back.

In the domestic backdrop, between 2003 and 2015, Brazil had experienced a credit easing cycle in a period defined by its relative economic stability. This expansion on the availability of resources started with non earmarked credit to households. Corporate sector lending had its growth intensified only in the period 2007-2008 by public banks, as a countercyclical policy to reduce the effects of the financial crisis. Consequently, total credit to non-financial sector increased from 19\% of GDP in 2007 to 27\% GDP in 2012. For the exporting sector, however, the special requirements of its credit instruments, the dependence of the international market on the determination of interest rates and even the direct dependence of international funds, made it more difficult to create specific countercyclical policies.

In this regard, it is possible to assume that this temporary setback arguably meant 
a cash flow shock to exporters only. But does this natural experiment really translated into changes in the cost of finance for the corporate sector? When investment opportunities are controlled for, were exporting firms more or less constrained than their peers at the time? My work attempts to identify this heterogeneity in credit constraints among the corporate sector during the Global Trade Collapse in 2009. 



\section{Estimation Methodology}

My basic insight is to exploit how the rising in the cost of credit to exporters, at the onset of the 2009 Global Trade Collapse, translated into real credit constraints for this group of firms. This study's identification strategy starts by designating the group of interest, hence, the type of exporter to be grouped as "treatment" in this analysis. It is intuitive to assume that the higher is a firm's dependence to foreign markets, the greater will be its reliance on credit instruments to ease liquidity issues brought by exporting markets. Therefore, it would be naive to include all exporting firms in the treatment category. Instead, I choose to include only export-intensive, defined here as firms that obtain at least 50 percent of their total revenue from exports in the year of 2009, the critical year for international trade ${ }^{1}$. Firms classification groups are defined as follows:

Table 1 - Exporting Criteria

\begin{tabular}{ll}
\hline Category & Exports-to-sales ratio \\
\hline Non-exporters & $0 \%$ \\
Intermediate exporters & Greater than 0\%, but less than $50 \%$ \\
Export-intensive firms & Greater than $50 \%$ \\
\hline
\end{tabular}

It is necessary to account for the fact that exporting firms potentially have specific observable characteristics underrepresented in the sample. Given the size and heterogeneity of it, the best strategy is to look for control units, the non-exporting firms, that can "match" the exporting ones in multiple features (covariates). More specifically, I employ the Nearest Neighbor matching estimator to a vector of exogenous covariates across treated and nontreated firms to find matched control firms and estimate their weights.

Further, to establish a causal effect between financial structure and real investment, I employ a weighted linear regression, with the weights previously found in matching and accounting for observable fixed effects. As I am mostly interested in studying credit constraints, the outcome regression must focus on the causal effect of this cash flow variation on investment spending. The model has the following specification:

$$
\begin{gathered}
\text { Investment }_{i, t}=\beta_{0}+\sum_{t \in \text { Years }} \beta_{1}^{t} \text { Treatment }_{i} * \text { Year }_{t}+\beta_{2} \text { CashFlow }_{i, t} / K_{i, t-1} \\
+\sum_{t \in \text { Years }} \beta_{3}^{t} \text { Treatment }_{i} * \text { Year }_{t} * \text { CashFlow }_{i, t} / K_{i, t-1}+\beta_{4} \Delta \text { Sales }_{i, t-1} \\
+v_{i}+v_{t}+\epsilon_{i, t}
\end{gathered}
$$

\footnotetext{
${ }^{1}$ Same definition of Coulibaly, Sapriza and Zlate (2013)
} 
where Investment $t_{i, t}$ is the investment of firm i at time $t$, proxied by the annual variation of fixed assets, divided by fixed assets in $t-1$ to eliminate size effects from our variable. The definition of investment diverges in the literature between the use of net change in tangible fixed assets, i.e., property, plant and equipment, and net change in total fixed assets. In this study, I chose the latter, which includes the variation of intangibles and R\&D expenses, since I am dealing with sectors that differ considerably in the use of tangible assets.

The independent variable, CashFlow ${ }_{i, t} / K_{i, t-1}$, is the ratio of cash flow (net profits plus depreciation) in $t$ over fixed assets in $t-1$, which is the classic measure of the availability of internal funds, i.e., the amount of resources left after the firm financed all its projects in the period. In the presence of imperfections in the credit market, the estimated $\beta_{2}$ should be positive and statistically significant if the firms' investment is sensitive to the generate cash flow. Similar to the original FHP accelerator model, in order to control for investment opportunities, $\Delta$ Sales $_{i, t-1}$ is added.

Additionally, since the effects of the crisis and credit market's interventions are of great interest here, I combine interactions between treatment group with the year dummy (Treatment $_{i} *$ Year), and the cash flow continuous variable all together (Treatment T $_{i} *$ Year $*$ CashFlow $\left._{i, t} / K_{i, t-1}\right)$. If the coefficient of the last interaction $\left(\beta_{3}\right)$ is somewhat larger/smaller for the treatment group, it means that exporters faced different credit conditions at the time.

The error terms comprise three components: $v_{i}$ is the firm-specific fixed effect, $v_{t}$ is the time dummy set controlling for possible changes in the macroeconomic environment of each year and $\epsilon_{i, t}$ is the firm idiosyncratic component. Further, robustness and placebo tests provide enough confidence in the validity of this identifying assumption. 


\section{Data Overview and Matching}

\subsection{Data}

I employ a unique dataset drawn from annual tax return reports filed by firms based in the state of Sao Paulo (which accounts for almost half of the companies in Brazil) over the period 2007-2013, and compiled by the Brazilian Internal Revenue Service (IRS) data systems. According to the Brazilian fiscal legislation, tax return reports covering complete accounting information are only mandatory for companies with gross profits over 6.5 million reais (about US\$2MM). Therefore, part of the small firms in the state are absent from this sample.

Following the literature, firms with less than 50 employees were removed, as well as firms that lacked complete records of the main regression variables. Observations with negative sales were also dropped. To control for the potential influence of outliers, I excluded observations whose capital expenditures (investment) and sales increased or decreased by more than 100\%. Finally, for cash flow over fixed assets ratio - our main independent variable - I excluded only sufficiently extreme values, which are more likely to be reporting mistakes than genuine extreme results. ${ }^{1}$

The final dataset covers 27,823 different firms, which corresponds to 131,067 firmyear observations, as presented in Table 2. It is an unbalanced panel, with the number of observations ranging from a minimum of 20,220 in 2013 to a maximum of 21,378 in 2011 . These are mainly unlisted firms operating in twenty different sectors defined according to the Brazilian National Classification of Economic Activities (CNAE). ${ }^{2}$ Table 2 also shows the representativeness of the sample in the overall population of firms, including the total number of firms and the number of firms defined as export-intensive.

Concerning the exporting sector, the percentage of firms in the sample which during the period 2008-2013 has had some revenue from exports corresponds to roughly $26 \%$. Less than $5 \%$ could be considered as "Export-intensive", and around 0.5\% "Export-intensive" specifically in the year of 2009. ${ }^{3}$ According to the Brazilian Institute of Geography and Statistics (IBGE) and the Ministry of Industry, Foreign Trade and Services (MDIC), there was an average number of 252,124 firms in Brazil with more than 50 employees in the

\footnotetext{
${ }^{1}$ Observations with cash-flow over 100 times higher than fixed assets were considered extreme.

${ }^{2}$ Due to fiscal confidentiality rules, companies are not identified and their given sectors, from the ninety-nine divisions of the CNAE, were aggregated into eighteen new divisions.

${ }^{3}$ Export-intensive, as defined previously, are firms at some year from 2008 to 2013 had more than 50\% of their revenue obtained with exporting activities.
} 
same period, 21,600 of which were exporters $(8 \%) .{ }^{4}$

Table 2 - Sample Size by Category

\begin{tabular}{lrrr}
\hline Firms & Number of Obs. & Number of Firms & Estimated Population \\
\hline Total (over 50 employees) & 131,067 & 27,823 & 252,124 \\
Exporters & 28,164 & 7,347 & 21,600 \\
Export-intensive & 3,234 & 1,425 & - \\
Export-intensive in 2009 & 1,037 & 130 & - \\
\hline
\end{tabular}

Source: CEMPRE-IBGE, Ministry of Industry, Foreign Trade and Services (MDIC) and Brazilian IRS. Note: Number of Observations and number of firms refer to the dimensions of the sample. Estimated population refers to the overall average number of catalogued firms at MDIC website. It is not possible to know whether firms are export-intensive once their exports-to-sales ratio is not reveled.

\subsection{Matching Analysis}

My goal is to the test whether funding constraints at the time of a global trade crisis altered decisions related to investments. In this intent, it is necessary to conceive an identification strategy that resembles an "experiment" in which a firm's demand for these credit instruments coincide with the developments in the financial markets crisis. The challenge is to estimate firms' investment level if had they not been relying on export credit lines on the midst of the financial crisis. But since I am dealing with non-experimental data and cannot reckon that firms are randomly assigned to be "exporter-intensive", the best approach is to build a control group for them to, later, estimate the differences, between the two groups, in investments-cash flow sensitivity during the time of the experiment and after it.

The construction of this control group requires, firstly, the search for available covariates that are causing an imbalance between the treated and untreated groups. However, since most financial variables are reportedly endogenous to credit constraints, I rely solely on exogenous firm characteristics such as size and sector. Figure 6 displays the differences between the total sample and exporters in terms of these two attributes. The total sample comprises mostly small firms, while the exporting firms, as expected, is in great proportion composed of large firms. There is also a sector-wise disproportion: Wholesale and Retail Trade activities are by far the most representative sector of the total sample, encompassing almost $40 \%$ of firms, but for exporters its prevalence juxtaposes with Administrative and Support activities; corresponding each to roughly $20 \%$ of the exporters' sample.

\footnotetext{
${ }^{4}$ The total number of firms is around $4.8 \mathrm{M}$, but it includes a large number of "nonemployer" firms such as freelance workers and single entrepreneurs acting as service suppliers.
} 
Figure 6 - Total Sample versus Exporters Comparison (\% by Number of Firms)

(a) Size by Number of Employees

Total

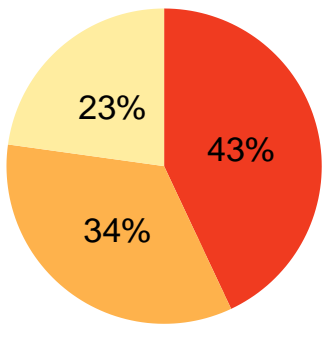

\section{Exporters}

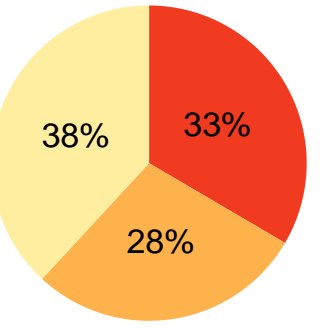

Large Medium Small

(b) Size by Total Assets within Sector

Total

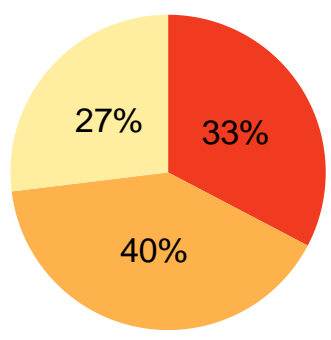

\section{Exporters}

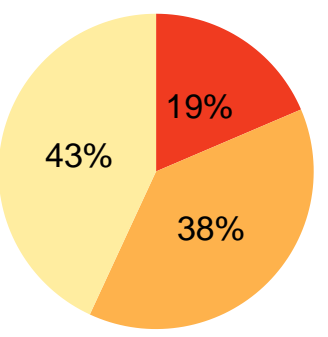

$$
\text { Large Medium Small }
$$

(c) Sector Breakdown

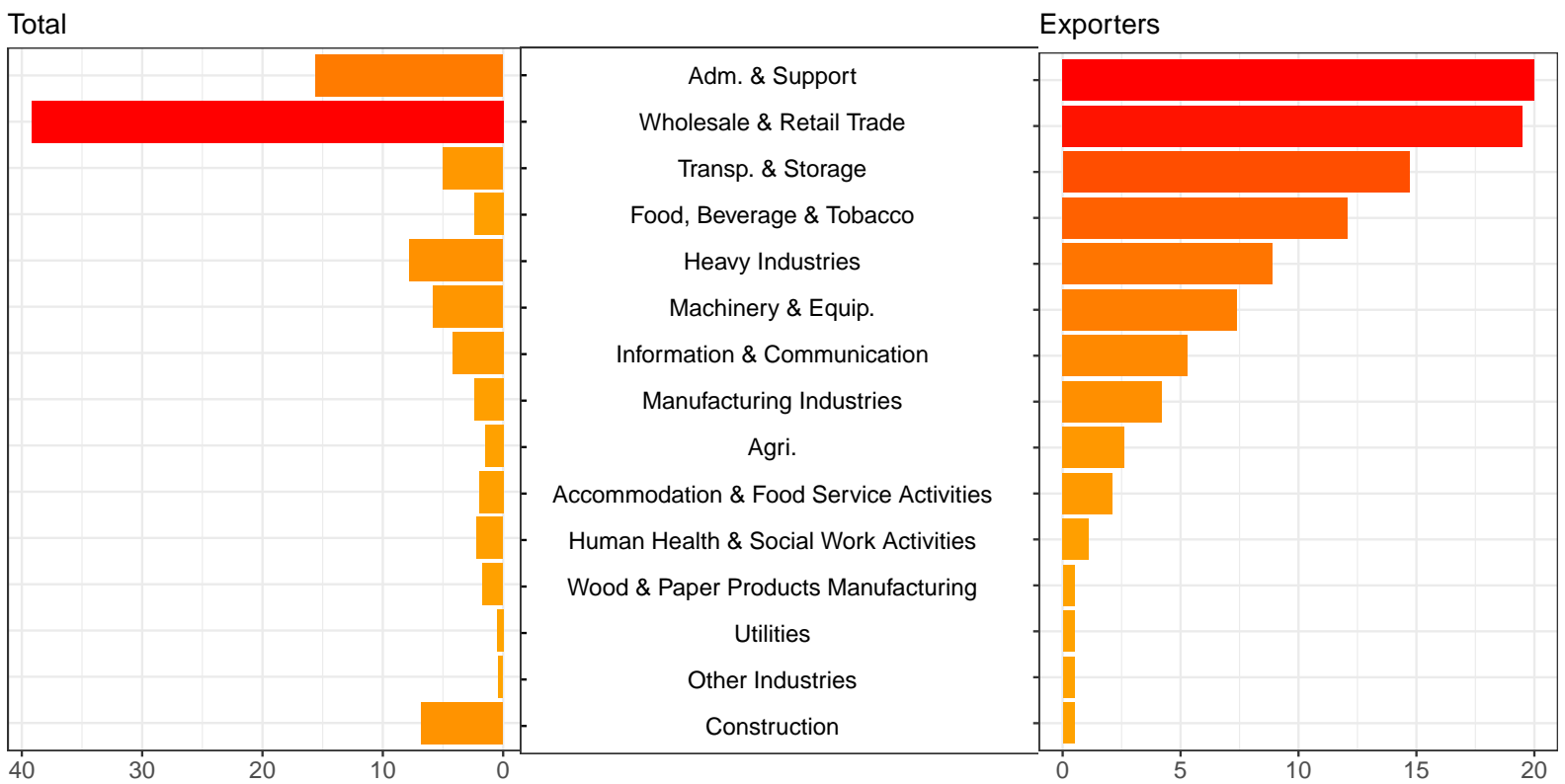

To begin, it is necessary to divide the sample according to their exports-to-sales ratio: "export-intensive" are the treatment and only the companies with no export activity 
in the period of 2008-2013 are defined as non-treated. This prevents companies near the $50 \%$ threshold of exports-to-sales ratio in 2009 from joining the "control" group, which would invalidate the most crucial assumption of the experiment: that firms affected by the shock are compared with the unaffected ones. Therefore, I specifically pair up firms in these two groups on the basis of their size - by number of employees (GFIP) and total assets within their sectors - and industry classification, assuming all these characteristics are constant from the year they enter the sample throughout the analyzed period. Typically, a matching is done by picking one participant in the control to each participant in the treatment. But since the size of the non-treated group in this case is more than 50 times larger than the size of the treatment group, I opted for a 1-to-4 matching. Having more individuals from the control group matched to every individual in the treatment group generates better estimates for the counter-factual.

After choosing the appropriate covariates, statistical tests are used to determine if they are well balanced across control and treatment groups before and after the matching. Table 3 shows the means of control and treatment groups for relevant variables to the model, their standardized differences (also known as Cohen's (1988) distance, a size comparison between two means divided by their pooled standard deviation); and weighted t-tests, that attempt to determine if two groups' means differ significantly.

The Nearest Neighbor matching estimator is used to minimize the distance between a vector of observed covariates across treated and non-treated firms, finding controls based on matches for which the distance between vectors is the smallest. As shown in Table 3, there is a improvement in the alikeness between the two distributions after the match. The statistically significant $p$-values suggests the rejection of the null hypothesis that the two populations have equal means in Panel A in terms of size by number of employees (GFIP) and sector. In Panel B, as expected, all differences between these means become insignificant. 
Table 3 - Balance Summary

Panel $A$ - Balance for all data:

\begin{tabular}{lcccc} 
Covariates & Means Treated & Means Control & Std. Diff. & Welch's t-test \\
\hline Distance & 0.03 & 0.02 & & \\
Size - Assets within Sector & 2.03 & 2.11 & 10.00 & 0.28 \\
Size - GFIP & 1.73 & 2.05 & 41.63 & 0.00 \\
Sector & 9.10 & 11.40 & 41.25 & 0.00 \\
\hline Number of Firms & 129 & 5,044 & & \\
\hline
\end{tabular}

Panel B - Balance for only matched data:

\begin{tabular}{lcccc} 
Covariates & Means Treated & Means Control & Std. Diff. & Welch's t-test \\
\hline Distance & 0.03 & 0.03 & & \\
Size - Assets within Sector & 2.03 & 2.02 & 5.66 & 0.57 \\
Size - GFIP & 1.73 & 1.73 & 8.47 & 0.40 \\
Sector & 9.10 & 9.05 & 2.25 & 0.82 \\
\hline Number of Fims & 129 & 453 & & \\
\hline
\end{tabular}

Note: The standardized difference (Cohen's $D$ ) is the difference between the means, $\mu_{\text {Treated }}-\mu_{C o n t r o l}$, divided by their pooled standard deviation. A reduction in the standard difference size indicates an improvement in variables' distance. The Welch two-sample location test is used to test the hypothesis that two populations have equal means (the null hypothesis). This test is an adaptation of Student's t-test. It is a more reliable test when the two samples have unequal variances and unequal sample sizes. Welch's test p-value is reported above. 



\section{Results}

\subsection{The Investment Response}

Figure 7 depicts the annual variation of the two most relevant variables to the model, investment and cash flow, for the matched sample. In 2009, exporters' cash flow net change decreased 9.4 percentage points (from minus $28.9 \%$ to minus $38.3 \%$ ) and their investment rates felt 3.7 percentage points (from minus $4.2 \%$ to minus $7.9 \%$ ), whereas non-exporters had a cash flow decrease of 13.1 percentage points (from minus $1.5 \%$ to minus $14.6 \%$ ) points and an investment rate's decline of 5.5 percentage points (from minus $0.5 \%$ to minus $6.0 \%$ ).

Figure 7 - Treated and Control Groups - Investments and Cash Flow (Annual Var. \% Median)

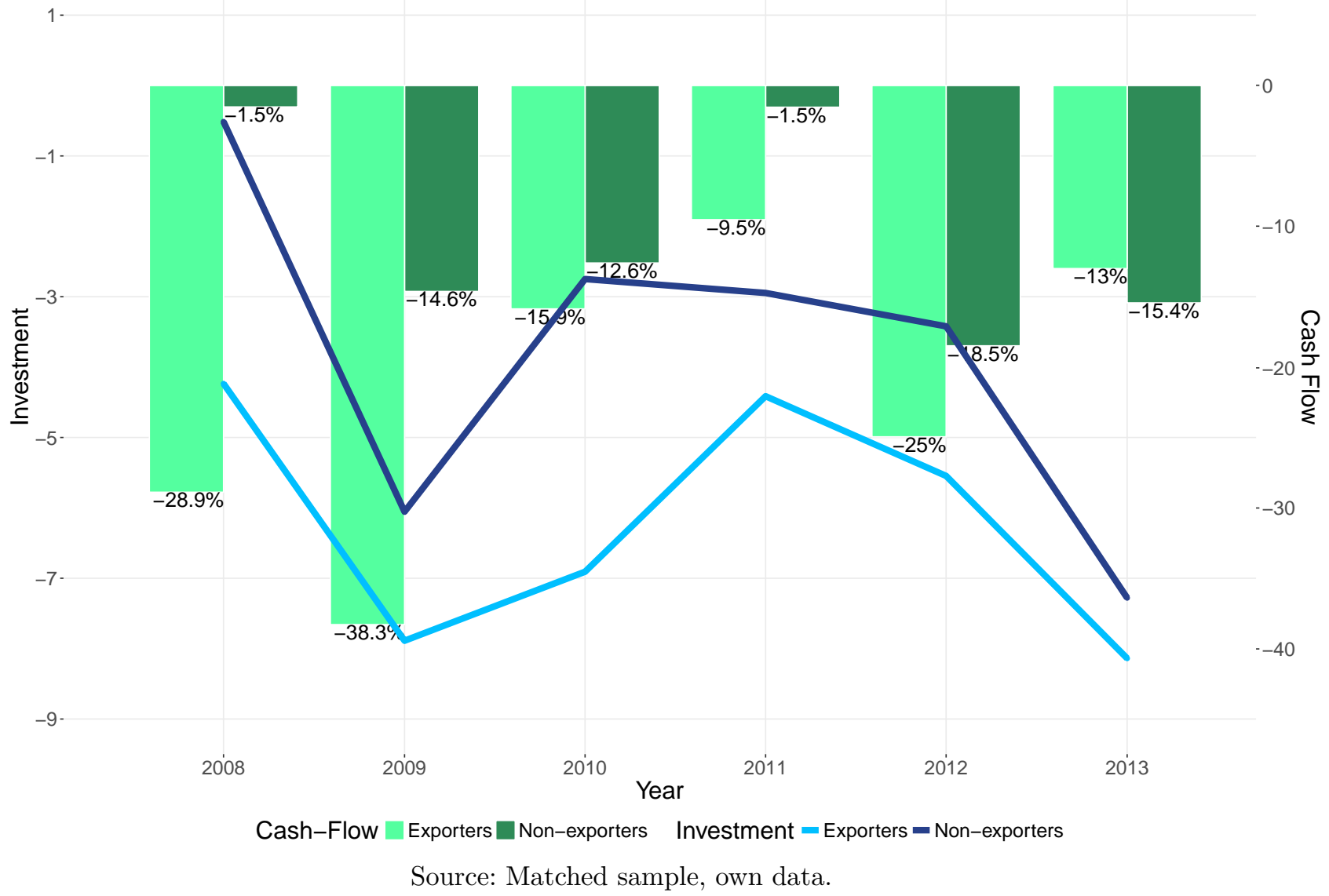

Due to the calculation of growth rates for assets and sales, one year of the initial sample size is lost; hence, only data from 2008 to 2013 is included. Table 4 shows sample 
means for a number of firms' variables during the period. ${ }^{1}$ There is a clear distinction of financial distress between treatment and control group in 2009: on average, although exporters generate higher levels of cash flow compared to the control group, their investment ratio felt more abruptly. Also, exporters average leverage ratios in the period reached its lowest. According to Faulkender and Petersen (2005), this can be another evidence of the distress in the period. The costs of monitoring and of imperfect financial contracting raise the costs of debt capital for these firms on times of instability. Consequently, this will lower their desired leverage.

Table 4 - Treated and Control Groups - Variable Means

\begin{tabular}{|c|c|c|c|c|c|c|c|}
\hline Variable & Group & 2008 & 2009 & 2010 & 2011 & 2012 & 2013 \\
\hline \multirow[t]{3}{*}{ Investment } & Treated & 0.02 & -0.07 & -0.01 & 0.00 & -0.05 & -0.06 \\
\hline & Control & 0.06 & -0.01 & 0.05 & 0.02 & -0.01 & -0.05 \\
\hline & Untreated & 0.00 & -0.04 & -0.02 & -0.02 & -0.03 & -0.05 \\
\hline \multirow[t]{3}{*}{ Cash-Flow Growth } & Treated & -1.07 & -0.57 & -0.35 & -0.54 & -0.49 & -0.02 \\
\hline & Control & -0.19 & -0.07 & -0.04 & 0.48 & -0.42 & 0.04 \\
\hline & Untreated & -0.07 & -0.22 & -0.08 & -0.19 & -0.26 & -0.14 \\
\hline \multirow[t]{3}{*}{ Cash Flow / Fixed Assets } & Treated & 1.28 & 1.27 & 1.44 & 2.18 & 1.49 & 1.75 \\
\hline & Control & 1.09 & 0.93 & 1.24 & 1.16 & 1.24 & 1.23 \\
\hline & Untreated & 0.83 & 0.81 & 0.99 & 0.96 & 0.86 & 0.80 \\
\hline \multirow[t]{3}{*}{ Sales Growth } & Treated & 0.05 & -0.05 & 0.04 & 0.07 & 0.05 & 0.02 \\
\hline & Control & 0.08 & -0.04 & 0.06 & 0.02 & 0.01 & -0.04 \\
\hline & Untreated & 0.04 & -0.08 & 0.03 & 0.01 & -0.02 & -0.03 \\
\hline \multirow[t]{3}{*}{ Leverage } & Treated & 0.71 & 0.68 & 0.73 & 0.84 & 0.90 & 1.30 \\
\hline & Control & 0.77 & 0.80 & 0.81 & 0.87 & 0.92 & 1.01 \\
\hline & Untreated & 1.26 & 1.15 & 1.18 & 1.30 & 1.18 & 1.31 \\
\hline \multirow[t]{3}{*}{ Colateral } & Treated & 0.28 & 0.27 & 0.27 & 0.25 & 0.22 & 0.21 \\
\hline & Control & 0.31 & 0.30 & 0.28 & 0.28 & 0.26 & 0.25 \\
\hline & Untreated & 0.25 & 0.24 & 0.24 & 0.24 & 0.23 & 0.22 \\
\hline \multirow[t]{3}{*}{ Liquidity } & Treated & 0.12 & 0.14 & 0.12 & 0.12 & 0.12 & 0.11 \\
\hline & Control & 0.05 & 0.06 & 0.04 & 0.01 & -0.01 & -0.05 \\
\hline & Untreated & -0.21 & -0.17 & -0.15 & -0.24 & -0.13 & -0.23 \\
\hline
\end{tabular}

Note: Treated observations are firms that had more than $50 \%$ of their revenue obtained with exporting activities in 2009. The control group refers to their domestically-oriented counter-parts, i.e., firms with no exporting activity that were paired up with the treatment group on the basis of sector, size by number of employees and size by total assets value within sector. The untreated group corresponds to the broader group of firms in the dataset out of the treated group.

\footnotetext{
${ }^{1}$ For a more detailed definition of the variables, see Appendix A.
} 


\subsection{Baseline Results}

Table 5 presents the model-based estimation of equation 3.1. Column (1) has the estimated coefficients of the equation without any investment opportunities control. Column (2) includes this control. In both cases, the cash flow over fixed assets (CashFlow/K) estimated parameter is positive and significant, consistent with the presence of financial constraints. These constraints, in line with my hypothesis, are higher for exportintensive firms during the Global Trade Collapse (Treatment*Cash-Flow/K*Year2009 coefficient is positive and significant). As column (2) depicts, in the year of 2009, for domestically-oriented firms (the control group), the baseline specification indicates that a one point decrease in cash flow to fixed assets ratio would represent $0.7 \%$ reduction of capital expenditures on average while for export-intensive firms this value is added with the Treatment*Cash-Flow $/ \mathrm{K}^{*}$ Year estimated coefficient. Thus, one point decrease in cash flow to fixed assets ratio would lead to $2.6 \%$ reduction of exporters capital expenditures on average.

In later years, the coefficient of this interaction variable decreases gradually but no statistically significant effect is present, which suggests that exporters were more constrained than their domestic market-focused peers at the time of the trade collapse. After Brazil's external commerce recovered from the disturbance, investment became less sensitive to cash flow - the coefficients of the two groups (treatment and control) are almost even in 2011 and 2012. These results provides evidence that higher spreads and credit-lines drawdowns had its share of responsibility on the decline of exporters' investment spending. ${ }^{2}$

When subject to scrutiny, the fact that the sample has an unbalanced panel format could invalidate the consistence of the results, once one could argue that constrained exporters might have left the sample in 2009 whereas the unconstrained ones remained because they had sufficient resources to face the turmoil. However, as seem in Table 13, in the Appendix, the data used here is characterized for its high persistence. Almost half of the companies encompassing the sample are observed throughout the analyzed period, eliminating the likelihood of having a biased treatment group in the post-crisis period.

\footnotetext{
${ }^{2}$ A dynamic version of Equation 3.1 (adding the lagged dependent variable) was also estimated via First-difference GMM (Arellano and Bond (1991)) and system GMM estimator (Blundell and Bond (1998)). But the results were discarded because the lagged investment variable was not significant.
} 
Table 5 - Fixed Effects Estimation

\begin{tabular}{|c|c|c|}
\hline & \multicolumn{2}{|c|}{ Dependent variable: } \\
\hline & \multicolumn{2}{|c|}{ Investment } \\
\hline & $(1)$ & $(2)$ \\
\hline Treatment*Cash-Flow/K*Year2009 & $\begin{array}{l}0.019^{* * *} \\
(0.005)\end{array}$ & $\begin{array}{c}0.019^{* *} \\
(0.008)\end{array}$ \\
\hline Treatment*Cash-Flow/K*Year2010 & $\begin{array}{c}0.012 \\
(0.179)\end{array}$ & $\begin{array}{c}0.013 \\
(0.156)\end{array}$ \\
\hline Treatment*Cash-Flow/K*Year2011 & $\begin{array}{c}0.002 \\
(0.611)\end{array}$ & $\begin{array}{c}0.004 \\
(0.309)\end{array}$ \\
\hline Treatment*Cash-Flow/K*Year2012 & $\begin{array}{c}0.001 \\
(0.756)\end{array}$ & $\begin{array}{c}0.001 \\
(0.756)\end{array}$ \\
\hline Treatment*Year2009 & $\begin{array}{r}-0.051 \\
(0.099)\end{array}$ & $\begin{array}{r}-0.063 \\
(0.082)\end{array}$ \\
\hline Treatment*Year2010 & $\begin{array}{r}-0.039 \\
(0.293)\end{array}$ & $\begin{array}{r}-0.053 \\
(0.203)\end{array}$ \\
\hline Treatment*Year2011 & $\begin{array}{c}0.011 \\
(0.733)\end{array}$ & $\begin{array}{c}-0.005 \\
(0.904)\end{array}$ \\
\hline Treatment*Year2012 & $\begin{array}{r}-0.014 \\
(0.665)\end{array}$ & $\begin{array}{r}-0.028 \\
(0.470)\end{array}$ \\
\hline Cash-Flow/K & $\begin{array}{c}0.007^{* * *} \\
(0.0001)\end{array}$ & $\begin{array}{c}0.007^{* * *} \\
(0.0002)\end{array}$ \\
\hline Lagged $\Delta$ Sales & & $\begin{array}{c}0.017 \\
(0.511)\end{array}$ \\
\hline Observations & 3,540 & 2,950 \\
\hline $\mathrm{R}^{2}$ & 0.268 & 0.300 \\
\hline Adjusted $\mathrm{R}^{2}$ & 0.118 & 0.120 \\
\hline Residual Std. Error & $0.261(\mathrm{df}=2936)$ & $0.260(\mathrm{df}=2346)$ \\
\hline
\end{tabular}

Note: Columns (1) and (2) show the fixed effects regression coefficients of equation 3.1 firstly without controlling for investment opportunities and later adding Lagged $\Delta$ Sales as the investment opportunities control. Time and sector dummies were included in all specifications. Standard errors and test statistics are asymptotically robust to heteroskedasticity. 


\subsection{Robustness Tests}

Next, three different robustness check strategies are performed (summarized in Table 6). The first one is to modify the treatment group. First, the group of "exportintensive" firms is enlarged: companies whose exports-to-sales ratio corresponds to more than or equal to $75 \%$ are allocated in this category. Second, the treatment group is narrowed: the "export-intensive" group is defined as those firms whose exports-to-sales ratio are more than or equal to $25 \%$. In both estimations, the main variable of interest, Treatment*Cash-Flow/K*Year2009 remains significant. Tables 7 and 8 present the results of these two tests that can confirm that my results are robust to changes on the treatment group.

The next test involves changing the matching ratio for the nearest neighbor matching. I perform 1-to-2 matching (every firm in the treatment group should be compared with two firms in the control group) and 1-to- 8 matching. Tables 9 to 10 show the results of such tests. And, in the third test, Table 11, I include the level of cash flow to fixed assets ratio in 2008 (pre-crisis) as a covariate on the matching. My earlier results are robust to all these tests.

Table 6 - Robustness Tests Definition

Test 1 - Changes in treatment group definition

Smaller group Treatment group defined as firms with exports-to-sales ratio over $75 \%$

Large group

Treatment group defined as firms with exports-to-sales ratio over $25 \%$

Test 2 - Changes in matching ratio

1-to-2 matching $\quad$ Every treatment must have two controls

1-to-8 matching Every treatment must have eight controls

Test 3 - Changes in matching covariates

Lagged cash flow adition Matching is done by adding the Cash Flow/K in 2008 as a covariate 
Table 7 - Robustness Test 1 - Treatment with exports-to-sales ratio over $75 \%$

\begin{tabular}{|c|c|c|}
\hline & \multicolumn{2}{|c|}{ Dependent variable: } \\
\hline & \multicolumn{2}{|c|}{ Investment } \\
\hline & $(1)$ & $(2)$ \\
\hline Treatment*Cash-Flow/K*Year2009 & $\begin{array}{l}0.019^{* * *} \\
(0.006)\end{array}$ & $\begin{array}{l}0.021^{* * *} \\
(0.006)\end{array}$ \\
\hline Treatment*Cash-Flow/K*Year2010 & $\begin{array}{c}0.010 \\
(0.292)\end{array}$ & $\begin{array}{c}0.013 \\
(0.192)\end{array}$ \\
\hline Treatment*Cash-Flow/K*Year2011 & $\begin{array}{r}-0.002 \\
(0.648)\end{array}$ & $\begin{array}{c}0.001 \\
(0.833)\end{array}$ \\
\hline Treatment*Cash-Flow/K*Year2012 & $\begin{array}{r}-0.001 \\
(0.890)\end{array}$ & $\begin{array}{c}0.001 \\
(0.845)\end{array}$ \\
\hline Treatment*Year2009 & $\begin{array}{c}-0.088^{* * *} \\
(0.027)\end{array}$ & $\begin{array}{c}-0.105^{* * *} \\
(0.028)\end{array}$ \\
\hline Treatment*Year2010 & $\begin{array}{c}0.011 \\
(0.814)\end{array}$ & $\begin{array}{r}-0.009 \\
(0.868)\end{array}$ \\
\hline Treatment*Year2011 & $\begin{array}{c}0.035 \\
(0.424)\end{array}$ & $\begin{array}{c}0.013 \\
(0.798)\end{array}$ \\
\hline Treatment*Year2012 & $\begin{array}{r}-0.010 \\
(0.838)\end{array}$ & $\begin{array}{r}-0.030 \\
(0.583)\end{array}$ \\
\hline Cash-Flow/K & $\begin{array}{l}0.012^{* * *} \\
(0.001)\end{array}$ & $\begin{array}{c}0.010 \\
(0.008)\end{array}$ \\
\hline Lagged $\Delta$ Sales & & $\begin{array}{c}0.036 \\
(0.307)\end{array}$ \\
\hline Observations & 2,256 & 1,880 \\
\hline $\mathrm{R}^{2}$ & 0.277 & 0.311 \\
\hline Adjusted $\mathrm{R}^{2}$ & 0.126 & 0.131 \\
\hline Residual Std. Error & $0.269(\mathrm{df}=1866)$ & $0.266(\mathrm{df}=1490)$ \\
\hline
\end{tabular}

Note: In this robustness test the group of "export-intensive" firms is enlarged: companies whose exports-to-sales ratio corresponds to more than or equal to $75 \%$ are allocated in this category. Columns (1) and (2) show the fixed Effects regression coefficients of equation 3.1 firstly without controlling for investment opportunities and later adding Lagged $\Delta$ Sales as the investment opportunities control. Time and sector dummies were included in all specifications. Standard errors and test statistics are asymptotically robust to heteroskedasticity. 
Table 8 - Robustness Test 1 - Treatment with exports-to-sales ratio over $25 \%$

\begin{tabular}{|c|c|c|}
\hline & \multicolumn{2}{|c|}{ Dependent variable: } \\
\hline & \multicolumn{2}{|c|}{ Investment } \\
\hline & $(1)$ & $(2)$ \\
\hline Treatment*Cash-Flow/K*Year2009 & $\begin{array}{l}0.027^{* * *} \\
(0.004)\end{array}$ & $\begin{array}{l}0.026^{* * *} \\
(0.008)\end{array}$ \\
\hline Treatment*Cash-Flow/K*Year2010 & $\begin{array}{c}0.014 \\
(0.121)\end{array}$ & $\begin{array}{c}0.014 \\
(0.124)\end{array}$ \\
\hline Treatment*Cash-Flow/K*Year2011 & $\begin{array}{c}0.002 \\
(0.595)\end{array}$ & $\begin{array}{c}0.003 \\
(0.410)\end{array}$ \\
\hline Treatment*Cash-Flow/K*Year2012 & $\begin{array}{c}0.003 \\
(0.536)\end{array}$ & $\begin{array}{c}0.002 \\
(0.629)\end{array}$ \\
\hline Treatment*Year2009 & $\begin{array}{c}-0.071^{* * *} \\
(0.008)\end{array}$ & $\begin{array}{r}-0.055 \\
(0.075)\end{array}$ \\
\hline Treatment*Year2010 & $\begin{array}{c}-0.067^{* *} \\
(0.031)\end{array}$ & $\begin{array}{c}-0.054 \\
(0.124)\end{array}$ \\
\hline Treatment*Year2011 & $\begin{array}{r}-0.026 \\
(0.364)\end{array}$ & $\begin{array}{c}-0.013 \\
(0.698)\end{array}$ \\
\hline Treatment*Year2012 & $\begin{array}{r}-0.021 \\
(0.461)\end{array}$ & $\begin{array}{r}-0.009 \\
(0.788)\end{array}$ \\
\hline Cash-Flow/K & $\begin{array}{c}0.008^{* * *} \\
(0.00002)\end{array}$ & $\begin{array}{c}0.008^{* * *} \\
(0.00003)\end{array}$ \\
\hline Lagged $\Delta$ Sales & & $\begin{array}{c}0.036 \\
(0.093)\end{array}$ \\
\hline Observations & 4,326 & 3,605 \\
\hline $\mathrm{R}^{2}$ & 0.263 & 0.298 \\
\hline Adjusted $\mathrm{R}^{2}$ & 0.112 & 0.118 \\
\hline Residual Std. Error & $0.253(\mathrm{df}=3591)$ & $0.252(\mathrm{df}=2870)$ \\
\hline
\end{tabular}

Note: In this robustness test the group of "export-intensive" firms is reduced: companies whose exports-to-sales ratio corresponds to more than or equal to $25 \%$ are allocated in this category. Columns (1) and (2) show the fixed Effects regression coefficients of equation 3.1 firstly without controlling for investment opportunities and later adding Lagged $\Delta$ Sales as the investment opportunities control. Time and sector dummies were included in all specifications. Standard errors and test statistics are asymptotically robust to heteroskedasticity. 
Table 9 - Robustness Test 2 - 1-to-2 matching

\begin{tabular}{|c|c|c|}
\hline & \multicolumn{2}{|c|}{ Dependent variable: } \\
\hline & \multicolumn{2}{|c|}{ Investment } \\
\hline & $(1)$ & $(2)$ \\
\hline Treatment*Cash-Flow/K*Year2009 & $\begin{array}{l}0.021^{\text {*** }} \\
(0.004)\end{array}$ & $\begin{array}{l}0.021^{* * *} \\
(0.007)\end{array}$ \\
\hline Treatment*Cash-Flow/K*Year2010 & $\begin{array}{c}0.014 \\
(0.123)\end{array}$ & $\begin{array}{c}0.016 \\
(0.107)\end{array}$ \\
\hline Treatment*Cash-Flow/K*Year2011 & $\begin{array}{c}0.005 \\
(0.126)\end{array}$ & $\begin{array}{c}0.007 \\
(0.022)\end{array}$ \\
\hline Treatment*Cash-Flow/K*Year2012 & $\begin{array}{c}0.004 \\
(0.314)\end{array}$ & $\begin{array}{c}0.005 \\
(0.306)\end{array}$ \\
\hline Treatment*Year2009 & $\begin{array}{c}-0.083^{* * *} \\
(0.015)\end{array}$ & $\begin{array}{r}-0.078 \\
(0.054)\end{array}$ \\
\hline Treatment*Year2010 & $\begin{array}{r}-0.043 \\
(0.279)\end{array}$ & $\begin{array}{c}-0.040 \\
(0.370)\end{array}$ \\
\hline Treatment*Year2011 & $\begin{array}{c}-0.041 \\
(0.252)\end{array}$ & $\begin{array}{c}-0.040 \\
(0.338)\end{array}$ \\
\hline Treatment*Year2012 & $\begin{array}{r}-0.073 \\
(0.056)\end{array}$ & $\begin{array}{c}-0.070 \\
(0.107)\end{array}$ \\
\hline Cash-Flow/K & $\begin{array}{c}0.003 \\
(0.191)\end{array}$ & $\begin{array}{c}0.002 \\
(0.489)\end{array}$ \\
\hline Lagged $\Delta$ Sales & & $\begin{array}{c}0.032 \\
(0.326)\end{array}$ \\
\hline Observations & 2,214 & 1,845 \\
\hline $\mathrm{R}^{2}$ & 0.258 & 0.295 \\
\hline Adjusted $\mathrm{R}^{2}$ & 0.104 & 0.111 \\
\hline Residual Std. Error & $0.264(\mathrm{df}=1831)$ & $0.264(\mathrm{df}=1462)$ \\
\hline
\end{tabular}

Note: In this robustness test a 1-to-2 matching is performed (every firm in the treatment group should be compared with two firms in the control group). Columns (1) and (2) show the fixed Effects regression coefficients of equation 3.1 firstly without controlling for investment opportunities and later adding Lagged $\Delta$ Sales as the investment opportunities control. Time and sector dummies were included in all specifications. Standard errors and test statistics are asymptotically robust to heteroskedasticity. 
Table 10 - Robustness Test 2 - 1-to- 8 matching

\begin{tabular}{|c|c|c|}
\hline & \multicolumn{2}{|c|}{ Dependent variable: } \\
\hline & \multicolumn{2}{|c|}{ Investment } \\
\hline & $(1)$ & $(2)$ \\
\hline Treatment*Cash-Flow/K*Year2009 & $\begin{array}{l}0.020^{* * *} \\
(0.004)\end{array}$ & $\begin{array}{l}0.020^{* * *} \\
(0.007)\end{array}$ \\
\hline Treatment*Cash-Flow/K*Year2010 & $\begin{array}{c}0.013 \\
(0.146)\end{array}$ & $\begin{array}{c}0.014 \\
(0.135)\end{array}$ \\
\hline Treatment*Cash-Flow/K*Year2011 & $\begin{array}{c}0.004 \\
(0.275)\end{array}$ & $\begin{array}{c}0.005 \\
(0.126)\end{array}$ \\
\hline Treatment*Cash-Flow/K*Year2012 & $\begin{array}{c}0.003 \\
(0.486)\end{array}$ & $\begin{array}{c}0.003 \\
(0.560)\end{array}$ \\
\hline Treatment*Year2009 & $\begin{array}{c}-0.068^{* * *} \\
(0.021)\end{array}$ & $\begin{array}{r}-0.057 \\
(0.099)\end{array}$ \\
\hline Treatment*Year2010 & $\begin{array}{r}-0.033 \\
(0.359)\end{array}$ & $\begin{array}{c}-0.023 \\
(0.558)\end{array}$ \\
\hline Treatment*Year2011 & $\begin{array}{r}-0.001 \\
(0.982)\end{array}$ & $\begin{array}{c}0.008 \\
(0.832)\end{array}$ \\
\hline Treatment*Year2012 & $\begin{array}{r}-0.026 \\
(0.428)\end{array}$ & $\begin{array}{r}-0.016 \\
(0.673)\end{array}$ \\
\hline Cash-Flow/K & $\begin{array}{l}0.005^{* * *} \\
(0.001)\end{array}$ & $\begin{array}{c}0.005^{*} \\
(0.003)\end{array}$ \\
\hline Lagged $\Delta$ Sales & & $\begin{array}{c}0.027 \\
(0.216)\end{array}$ \\
\hline Observations & 5,700 & 4,750 \\
\hline $\mathrm{R}^{2}$ & 0.243 & 0.283 \\
\hline Adjusted $\mathrm{R}^{2}$ & 0.089 & 0.100 \\
\hline Residual Std. Error & $0.266(\mathrm{df}=4736)$ & $0.264(\mathrm{df}=3786)$ \\
\hline
\end{tabular}

Note: In this robustness test a 1-to-8 matching is performed (every firm in the treatment group should be compared with eight firms in the control group). Columns (1) and (2) show the fixed Effects regression coefficients of equation 3.1 firstly without controlling for investment opportunities and later adding Lagged $\Delta$ Sales as the investment opportunities control. Time and sector dummies were included in all specifications. Standard errors and test statistics are asymptotically robust to heteroskedasticity. 
Table 11 - Robustness Test 3 - Adding Cash Flow covariate

\begin{tabular}{|c|c|c|}
\hline & \multicolumn{2}{|c|}{ Dependent variable: } \\
\hline & \multicolumn{2}{|c|}{ Investment } \\
\hline & $(1)$ & $(2)$ \\
\hline Treatment*Cash-Flow/K*Year2009 & $\begin{array}{l}0.019^{* * *} \\
(0.005)\end{array}$ & $\begin{array}{c}0.019^{* *} \\
(0.008)\end{array}$ \\
\hline Treatment*Cash-Flow/K*Year2010 & $\begin{array}{c}0.012 \\
(0.176)\end{array}$ & $\begin{array}{c}0.014 \\
(0.147)\end{array}$ \\
\hline Treatment*Cash-Flow/K*Year2011 & $\begin{array}{c}0.002 \\
(0.589)\end{array}$ & $\begin{array}{c}0.004 \\
(0.266)\end{array}$ \\
\hline Treatment*Cash-Flow/K*Year2012 & $\begin{array}{c}0.002 \\
(0.719)\end{array}$ & $\begin{array}{c}0.002 \\
(0.635)\end{array}$ \\
\hline Treatment*Year2009 & $\begin{array}{c}-0.071^{* * *} \\
(0.022)\end{array}$ & $\begin{array}{c}-0.078^{* *} \\
(0.031)\end{array}$ \\
\hline Treatment*Year2010 & $\begin{array}{r}-0.058 \\
(0.123)\end{array}$ & $\begin{array}{r}-0.067 \\
(0.106)\end{array}$ \\
\hline Treatment*Year2011 & $\begin{array}{r}-0.009 \\
(0.769)\end{array}$ & $\begin{array}{r}-0.020 \\
(0.585)\end{array}$ \\
\hline Treatment*Year2012 & $\begin{array}{r}-0.013 \\
(0.694)\end{array}$ & $\begin{array}{r}-0.025 \\
(0.508)\end{array}$ \\
\hline Cash-Flow/K & $\begin{array}{c}0.007 \\
(0.036)\end{array}$ & $\begin{array}{c}0.006 \\
(0.117)\end{array}$ \\
\hline Lagged $\Delta$ Sales & & $\begin{array}{l}0.065^{* * *} \\
(0.011)\end{array}$ \\
\hline Observations & 3,540 & 2,950 \\
\hline $\mathrm{R}^{2}$ & 0.264 & 0.307 \\
\hline Adjusted $\mathrm{R}^{2}$ & 0.112 & 0.129 \\
\hline Residual Std. Error & $0.262(\mathrm{df}=2936)$ & $0.259(\mathrm{df}=2346)$ \\
\hline
\end{tabular}

Note: In this robustness test the variable cash flow to fixed assets in 2008 (pre-crisis) is added as a covariate on the matching. Columns (1) and (2) show the fixed effects regression coefficients of equation 3.1 firstly without controlling for investment opportunities and later adding Lagged $\Delta$ Sales as the investment opportunities control. Time and sector dummies were included in all specifications. Standard errors and test statistics are asymptotically robust to heteroskedasticity. 


\subsection{Placebo Tests}

In order to strengthen the interpretation of the results, I construct a fake treatment group by randomly selecting a non-exporters subset with the same number of firms as the real treatment group. This estimation was repeated several times changing the firms selected to the fake treatment group. One of the results are reported below in Table 12. As expected, the estimated coefficients are insignificant for Cash Flow/K and Treatment $*$ Cash Flow/K*Year. 
Table 12 - Placebo Test - Fake treatment group

\begin{tabular}{|c|c|c|}
\hline & \multicolumn{2}{|c|}{ Dependent variable: } \\
\hline & \multicolumn{2}{|c|}{ Investment } \\
\hline & $(1)$ & $(2)$ \\
\hline Treatment*Cash-Flow/K*Year2009 & $\begin{array}{c}0.003 \\
(0.004)\end{array}$ & $\begin{array}{c}0.004 \\
(0.004)\end{array}$ \\
\hline Treatment*Cash-Flow/K*Year2010 & $\begin{array}{r}-0.003 \\
(0.003)\end{array}$ & $\begin{array}{r}-0.002 \\
(0.004)\end{array}$ \\
\hline Treatment*Cash-Flow/K*Year2011 & $\begin{array}{c}0.002 \\
(0.004)\end{array}$ & $\begin{array}{c}0.004 \\
(0.004)\end{array}$ \\
\hline Treatment*Cash-Flow/K*Year2012 & $\begin{array}{c}0.007 \\
(0.005)\end{array}$ & $\begin{array}{c}0.009^{* *} \\
(0.005)\end{array}$ \\
\hline Treatment*Year2009 & $\begin{array}{r}-0.013 \\
(0.019)\end{array}$ & $\begin{array}{r}-0.013 \\
(0.023)\end{array}$ \\
\hline Treatment*Year2010 & $\begin{array}{r}-0.015 \\
(0.020)\end{array}$ & $\begin{array}{r}-0.028 \\
(0.024)\end{array}$ \\
\hline Treatment*Year2011 & $\begin{array}{r}-0.022 \\
(0.020)\end{array}$ & $\begin{array}{r}-0.033 \\
(0.024)\end{array}$ \\
\hline Treatment*Year2012 & $\begin{array}{r}-0.013 \\
(0.021)\end{array}$ & $\begin{array}{r}-0.023 \\
(0.024)\end{array}$ \\
\hline Cash-Flow/K & $\begin{array}{c}0.002^{* *} \\
(0.001)\end{array}$ & $\begin{array}{c}0.001 \\
(0.001)\end{array}$ \\
\hline Lagged $\Delta$ Sales & & $\begin{array}{c}0.0002 \\
(0.001)\end{array}$ \\
\hline Year Effects & Yes & Yes \\
\hline Individual Effects & Yes & Yes \\
\hline Observations & 14,053 & 11,497 \\
\hline $\mathrm{R}^{2}$ & 0.330 & 0.377 \\
\hline Adjusted $\mathrm{R}^{2}$ & 0.145 & 0.154 \\
\hline Residual Std. Error & $0.288(\mathrm{df}=10998)$ & $0.284(\mathrm{df}=8474)$ \\
\hline
\end{tabular}

Note: The placebo test is performed with a fake treatment group, build by randomly selecting firms from the control group. Columns (1) and (2) show the fixed Effects regression coefficients of equation 3.1 firstly without controlling for investment opportunities and later adding Lagged $\Delta$ Sales as the investment opportunities control. Time and sector dummies were included in all specifications. Standard errors and test statistics are asymptotically robust to heteroskedasticity. 


\section{Concluding remarks}

This study provides a new piece of evidence that financial factors might have contributed to a greater decline in investments. As almost all the credit instruments designed to finance exporting activity rely on the availability of external financing in foreign currency, they are expected to be highly vulnerable to oscillations on international markets liquidity. Using the 2008-2009 financial crisis as a negative shock on the supply of credit to exporters, I estimate an modified version of the traditional investment regression, present in the FHP model, to show that Brazilian exporters were indeed more constrained than their domestically-oriented counterparts during this episode. Notwithstanding, funding shortage differences diminish and become insignificant as markets retrieved.

Although the effects of the 2009 crisis have been extensively analyzed, only a small set of papers present a firm-level evidence of its aftermaths on emerging markets, especially for Brazil, that has few private company data available. Perhaps given the difficulty of setting up a representative sample of our firm population, this is the first paper to gauge a causal effect between credit markets and exporters investment behaviour for the country. I do so by employing a unique dataset of firms, 130 of which export-intensive firms in 2009, paired with domestically-oriented firms based on several characteristics. My findings are in line with the existing literature on exporting activity dependence on external funding (CHOR; MANOVA, 2012; AMITI; WEINSTEIN, 2011; IACOVONE; ZAVACKA, 2009). The results reinforce the need of policy makers to explore the development of additional sources of financing for exporting activity, which might not be as essential in normal times, but could prove useful during crises when international credit markets become impaired. 



\section{References}

AĞCA, Şenay; MOZUMDAR, Abon. The impact of capital market imperfections on investment-cash flow sensitivity. Journal of Banking \& Finance, v. 32, n. 2, p. 207-216, 2008 .

AHN, JaeBin; AMITI, Mary; WEINSTEIN, David E. Trade finance and the Great Trade Collapse. American Economic Review, v. 101, n. 3, p. 298-302, 2011.

ALLAYANNIS, George; MOZUMDAR, Abon. The impact of negative cash flow and influential observations on investment-cash flow sensitivity estimates. Journal of Banking Ef Finance, v. 28, n. 5, p. 901-930, 2004.

ALMEIDA, Heitor; CAMPELLO, Murillo. Financial constraints, asset tangibility, and corporate investment. The Review of Financial Studies, v. 20, n. 5, p. 1429-1460, 2007.

ALMEIDA, Heitor; CAMPELLO, Murillo; LARANJEIRA, Bruno; WEISBENNER, Scott. Corporate debt maturity and the real effects of the 2007 credit crisis. Critical Finance Review, v. 1, p. 3-58, 2012.

AMITI, Mary; WEINSTEIN, David E. Exports and financial shocks. The Quarterly Journal of Economics, v. 126, n. 4, p. 1841-1877, 2011.

ARELLANO, Manuel; BOND, Stephen. Some tests of specification for panel data: Monte carlo evidence and an application to employment equations. The Review of Economic Studies, v. 58, n. 2, p. 277-297, 1991.

BAKKE, Tor-Erik; WHITED, Toni M. Threshold events and identification: A study of cash shortfalls. The Journal of Finance, v. 67, n. 3, p. 1083-1111, 2012.

BECK, Thorsten; DEMIRGÜÇ-KUNT, Aslı; LAEVEN, Luc; MAKSIMOVIC, Vojislav. The determinants of financing obstacles. Journal of International Money and Finance, v. 25, n. 6 , p. $932-952,2006$.

BEHRENS, Kristian; CORCOS, Gregory; MION, Giordano. Trade crisis? What trade crisis? Review of Economics and Statistics, v. 95, n. 2, p. 702-709, 2013.

BERNANKE, Ben S; LOWN, Cara S; FRIEDMAN, Benjamin M. The credit crunch. Brookings Papers on Economic Activity, n. 2, p. 205-247, 1991.

BLUNDELL, Richard; BOND, Stephen. Initial conditions and moment restrictions in dynamic panel data models. Journal of Econometrics, v. 87, n. 1, p. 115-143, 1998.

BRICONGNE, Jean-Charles; FONTAGNÉ, Lionel; GAULIER, Guillaume; TAGLIONI, Daria; VICARD, Vincent. Firms and the global crisis: French exports in the turmoil. Journal of International Economics, v. 87, n. 1, p. 134-146, 2012.

BROWN, James R; PETERSEN, Bruce C. Why has the investment-cash flow sensitivity declined so sharply? Rising R\&D and equity market developments. Journal of Banking $\mathscr{G}$ Finance, v. 33, n. 5, p. 971-984, 2009. 
CARPENTER, Robert E; GUARIGLIA, Alessandra. Cash flow, investment, and investment opportunities: New tests using UK panel data. Journal of Banking \& Finance, v. 32, n. 9, p. 1894-1906, 2008.

CARVALHO, Daniel. Financing constraints and the amplification of aggregate downturns. The Review of Financial Studies, v. 28, n. 9, p. 2463-2501, 2015.

CHAUFFOUR, Jean-Pierre; FAROLE, Thomas. Market adjustment versus market failure. Trade Finance during the Great Trade Collapse, World Bank Publications, 2011.

CHEN, Huafeng Jason; CHEN, Shaojun Jenny. Investment-cash flow sensitivity cannot be a good measure of financial constraints: Evidence from the time series. Journal of Financial Economics, v. 103, n. 2, p. 393-410, 2012.

CHEUNG, Calista; GUICHARD, Stephanie. Understanding the World Trade Collapse. OECD Economics Department Working Papers, n. 729, 2009.

CHEVALIER, Judith. What Do We Know About Cross-subsidization? Evidence from Merging Firms. The B.E. Journal of Economic Analysis \& Policy, v. 4, n. 1, p. 1-29, 2004.

CHOR, Davin; MANOVA, Kalina. Off the cliff and back? Credit conditions and international trade during the Global Financial Crisis. Journal of International Economics, v. 87, n. 1, p. 117-133, 2012.

COHEN, Jacob. Statistical power analysis for the behavioral sciences. 2. ed. Hillsdale, NJ: Lawrence Earlbaum Associates, 1988.

COULIBALY, Brahima; SAPRIZA, Horacio; ZLATE, Andrei. Financial frictions, trade credit, and the 2008-09 Global Financial Crisis. International Review of Economics $E_{3}$ Finance, v. 26, p. 25-38, 2013.

DUCHIN, Ran; OZBAS, Oguzhan; SENSOY, Berk A. Costly external finance, corporate investment, and the subprime mortgage credit crisis. Journal of Financial Economics, v. 97, n. 3, p. 418-435, 2010.

ERICKSON, Timothy; WHITED, Toni M. Measurement error and the relationship between investment and Q. Journal of Political Economy, v. 108, n. 5, p. 1027-1057, 2000.

FARRE-MENSA, Joan; LJUNGQVIST, Alexander. Do measures of financial constraints measure financial constraints? The Review of Financial Studies, v. 29, n. 2, p. 271-308, 2016.

FAULKENDER, Michael; PETERSEN, Mitchell A. Does the source of capital affect capital structure? The Review of Financial Studies, v. 19, n. 1, p. 45-79, 2005.

FAZZARI, Steven M; HUBBARD, R Glenn; PETERSEN, Bruce C; BLINDER, Alan S; POTERBA, James M. Financing constraints and corporate investment. Brookings Papers on Economic Activity, n. 1, p. 141-206, 1988.

GALETTI, Jefferson; HIRATUKA, Celio. Financiamento às exportações: Uma avaliação dos impactos dos programas públicos brasileiros. Revista de Economia Contemporânea, 2013. 
GAN, Jie. Collateral, debt capacity, and corporate investment: Evidence from a natural experiment. Journal of Financial Economics, v. 85, n. 3, p. 709-734, 2007.

GILCHRIST, Simon; HIMMELBERG, Charles P. Evidence on the role of cash flow for investment. Journal of Monetary Economics, v. 36, n. 3, p. 541-572, 1995.

GUARIGLIA, Alessandra. Internal financial constraints, external financial constraints, and investment choice: Evidence from a panel of UK firms. Journal of Banking $\&$ Finance, v. 32, n. 9, p. 1795-1809, 2008.

HAYASHI, Fumio. Tobin's marginal Q and average Q: A neoclassical interpretation. Econometrica, v. 50, n. 1, p. 213-224, 1982.

HOUSTON, Joel; JAMES, Christopher; MARCUS, David. Capital market frictions and the role of internal capital markets in banking. Journal of Financial Economics, v. 46, n. 2, p. 135-164, 1997.

HUBBARD, R Glenn. Capital-market imperfections and investment. Journal of Economic Literature, v. 36, n. 1, p. 193-225, 1997.

IACOVONE, Leonardo; ZAVACKA, Veronika. Banking crises and exports: Lessons from the past for the recent trade collapse. In: BALDWIN, Richard (Ed.). The Great Trade Collapse: causes, consequences and prospects. London, UK: Centre for Economic Policy Research, 2009. p. 107-114.

IMF. World Economic Outlook: Rebalancing Growth. Washington, DC, 2010.

KAPLAN, Steven N; ZINGALES, Luigi. Do investment-cash flow sensitivities provide useful measures of financing constraints? The Quarterly Journal of Economics, v. 112, n. 1, p. 169-215, 1997.

LAMONT, Owen. Cash flow and investment: Evidence from internal capital markets. The Journal of Finance, v. 52, n. 1, p. 83-109, 1997.

LAMONT, Owen; POLK, Christopher; SAAÁ-REQUEJO, Jesús. Financial constraints and stock returns. The Review of Financial Studies, v. 14, n. 2, p. 529-554, 2001.

LAWRENCE, Robert Z.; HANOUZ, Margareta Drzeniek; MOAVENZADEH, John. The Global Enabling Trade Report. London, UK, 2009.

LEARY, Mark T. Bank loan supply, lender choice, and corporate capital structure. The Journal of Finance, v. 64, n. 3, p. 1143-1185, 2009.

LEMMON, Michael; ROBERTS, Michael R. The response of corporate financing and investment to changes in the supply of credit. Journal of Financial and Quantitative Analysis, v. 45, n. 3, p. 555-587, 2010.

LEVCHENKO, Andrei; LEWIS, Logan; TESAR, Linda. The role of financial factors in the Great Trade Collapse: A Skeptic's View. In: CHAUFFOUR, Jean-Pierre; MALOUCHE, Mariem (Ed.). Trade finance during the Great Trade Collapse. Washington, DC: The World Bank, 2011. p. 133-147.

MODIGLIANI, Franco; MILLER, Merton H. The cost of capital, corporation finance and the theory of investment. The American Economic Review, v. 48, n. 3, p. 261-297, 1958. 
PARAVISINI, Daniel; RAPPOPORT, Veronica; SCHNABL, Philipp; WOLFENZON, Daniel. Dissecting the effect of credit supply on trade: Evidence from matched credit-export data. The Review of Economic Studies, v. 82, n. 1, p. 333-359, 2014.

RAUH, Joshua D. Investment and financing constraints: Evidence from the funding of corporate pension plans. The Journal of Finance, v. 61, n. 1, p. 33-71, 2006.

ROSSI, Pedro; PRATES, Daniela Magalhães. Financiamento às exportações no Brasil. Análise Econômica, v. 31, n. 59, 2010.

SHIN, Hyun-Han; STULZ, René M. Are internal capital markets efficient? The Quarterly Journal of Economics, v. 113, n. 2, p. 531-552, 1998.

VERMEULEN, Philip. Business fixed investment: evidence of a financial accelerator in Europe. Oxford Bulletin of Economics and Statistics, v. 64, n. 3, p. 213-231, 2002. 
Appendix 



\section{APPENDIX A - Data}

\section{A.1 Detailed variable definitions}

Fixed capital stock $(K)$ : book value of fixed assets

Fixed investment (I): difference between the book value of fixed assets of end of year $t$ and end of year $t-1$.

Cash flow $(C F)$ : net income plus depreciation.

Sales (S): firm's total sales minus returned and cancelled sales (including domestic and overseas sales).

Sales Growth: percentage of change in sales from one period to another.

Leverage: ratio of current liabilities plus non-current liabilities to total assets.

Liquidity: current assets minus current liabilities to total assets.

Collateral: tangible fixed assets over total assets.

Export Rate: ratio of exports to total sales.

Deflators: all growth variables are deflated using the Brazilian GDP Price Deflator (\% YoY).

\section{A.2 Sample Profile}

Table 13 - Dataset composition by number of observations per firm

\begin{tabular}{ccc}
\hline Number of obs. per firm & Number of firms & Percent \\
\hline 1 & 3,331 & 11.97 \\
2 & 3,703 & 13.31 \\
3 & 2,607 & 9.37 \\
4 & 2,272 & 8.17 \\
5 & 2,484 & 8.93 \\
6 & 2,981 & 10.71 \\
7 & 10,445 & 37.54 \\
\hline Total & 27,823 & 100 \\
\hline
\end{tabular}

